\title{
Mexican Oregano (Lippia graveolens Kunth) as Source of Bioactive Compounds: A Review
}

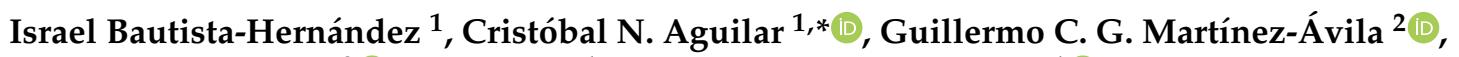

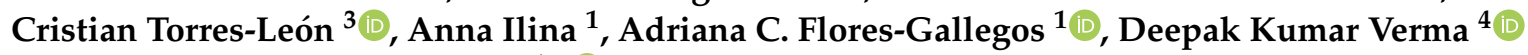 \\ and Mónica L. Chávez-González ${ }^{1, * \mathbb{B}}$
}

1 Bioprocesses and Bioproducts Research Group, Food Research Department, School of Chemistry, Universidad Autónoma de Coahuila, Saltillo 25280, Mexico; hernandez_israel@uadec.edu.mx (I.B.-H.); annailina@uadec.edu.mx (A.I.); carolinaflores@uadec.edu.mx or adrianaflores@uadec.edu.mx (A.C.F.-G.)

2 Laboratory of Chemistry and Biochemistry, School of Agronomy, Universidad Autónoma de Nuevo León, General Escobedo, Monterrey 66050, Mexico; guillermo.martinezavl@uanl.edu.mx

3 Ethnobiological Garden and Research Center-UadeC (CIJE), Universidad Autónoma de Coahuila, Saltillo 27480, Mexico; ctorresleon@uadec.edu.mx

4 Agricultural and Food Engineering Department, Indian Institute of Technology Kharagpur, Kharagpur 721 302, India; deepak.verma@agfe.iitkgp.ernet.in

* Correspondence: monicachavez@uadec.edu.mx (M.L.C.-G.); cristobal.aguilar@uadec.edu.mx (C.N.A.); Tel.: +52-844-4161238 (C.N.A.)

Citation: Bautista-Hernández, I.; Aguilar, C.N.; Martínez-Ávila, G.C.G.; Torres-León, C.; Ilina, A.; FloresGallegos, A.C.; Kumar Verma, D.; Chávez-González, M.L. Mexican Oregano (Lippia graveolens Kunth) as Source of Bioactive Compounds: A Review. Molecules 2021, 26, 5156. https://doi.org/10.3390/ molecules26175156

Academic Editors: Charng-Cherng Chyau and Lillian Barros

Received: 31 May 2021

Accepted: 13 July 2021

Published: 25 August 2021

Publisher's Note: MDPI stays neutral with regard to jurisdictional claims in published maps and institutional affiliations.

Copyright: (c) 2021 by the authors. Licensee MDPI, Basel, Switzerland. This article is an open access article distributed under the terms and conditions of the Creative Commons Attribution (CC BY) license (https:// creativecommons.org/licenses/by/ $4.0 /)$.

\begin{abstract}
Lippia graveolens is a traditional crop and a rich source of bioactive compounds with various properties (e.g., antioxidant, anti-inflammatory, antifungal, UV defense, anti-glycemic, and cytotoxicity) that is primarily cultivated for essential oil recovery. The isolated bioactive compounds could be useful as additives in the functional food, nutraceuticals, cosmetics, and pharmaceutical industries. Carvacrol, thymol, $\beta$-caryophyllene, and p-cymene are terpene compounds contained in oregano essential oil (OEO); flavonoids such as quercetin O-hexoside, pinocembrin, and galangin are flavonoids found in oregano extracts. Furthermore, thermoresistant compounds that remain in the plant matrix following a thermal process can be priced in terms of the circular economy. By using better and more selective extraction conditions, the bioactive compounds present in Mexican oregano can be studied as potential inhibitors of COVID-19. Also, research on extraction technologies should continue to ensure a higher quality of bioactive compounds while preventing an undesired chemical shift (e.g., hydrolysis). The oregano fractions can be used in the food, health, and agricultural industries.
\end{abstract}

Keywords: Lippia graveolens; bioactive compounds; phenolic compounds; extraction techniques

\section{Introduction}

Oregano includes many aromatic species, mostly from the Lamiaceae and Verbenaceae families, which form most of the world's commercially traded culinary herbs, primarily used for flavoring and traditional medicine for a variety of diseases (e.g., bacterial infections, digestive disorders, inflammatory diseases, and others) [1,2]. Furthermore, according to Cheikhyoussef et al. [3], the oregano crop is divided into four distinct groups: Turkish oregano (Origanum onites), Spanish oregano (Coridohymus capitatu), Greek oregano (Origanum vulgare) and Mexican oregano (Lippia graveolens). The Greek oregano (O. vulgare) has been the most studied oregano species, with many studies elucidating the potential as antioxidant, antimicrobial, antifungal, anti-inflammatory, and skin defensive auxiliaries associated with its rich polyphenolic fraction [4,5]. Similarly, several studies have been explored the potential of $L$. graveolens and other plants known as Mexican oregano synonyms (Poliomintha longiflora, Lippia berlandieri and Monarda Fistulosa var. Menthifolia) as auxiliary in oxidative disorders and antimicrobial properties [6-9]. 
In addition, oregano has been investigated as a source of bioactive compounds such as phenolic compounds, which are secondary metabolites produced by plants with antioxidant properties and a possible function in disease prevention [7-9]. The demand for bioactive compounds has increased; for example, the essential oil (EO) market is expected to hit $\$ 3226.2$ million by 2025 [10]. According to the Codex Alimentarius Commission [11], Mexico is the second largest source, primarily of L. graveolens Kunth, L. berlandieri Schauer, and, more recently, for the P. longiflora species. The Mexican commercialization sequence has some disadvantages for farmers because of intermediaries that market the product with industry without developing more complex economic strategies [12].

The oregano plant is primarily used for EO recovery; oregano essential oil (OEO) is made up of terpenes (monoterpenes and sesquiterpenes), which are responsible for the aroma and strong flavor [13]. The key components of OEO are thymol and carvacrol, which are found in aromatic plants such as thyme (Thymus vulgaris), epperwort (Lepidium flavum), black cumin (Nigella sativa), and others [14]. Oregano plants are also high in bioactive polyphenolic compounds. These molecules have been isolated from raw leaves as a byproduct of EO recovery. Even after a thermal extraction procedure, these by-products are a rich source of bioactive compounds [15].

In this context, the main purpose of this review article is to provide an overview of the L. graveolens and Mexican oreganos extraction techniques used for fraction recovery, chemical composition, variation, bioactivity, cultivation aspects, and intellectual property.

\section{Chemical Composition}

The oregano plant contains an essential oil fraction that generates most of its economic value as a flavoring and additive for food products. Furthermore, fresh leaves and wasted plant material have been suggested as a bioactive fraction and alternative source of bioactive compounds such as polyphenols (Flavonoids) and terpenes (Figure 1) with possible industrial applications.

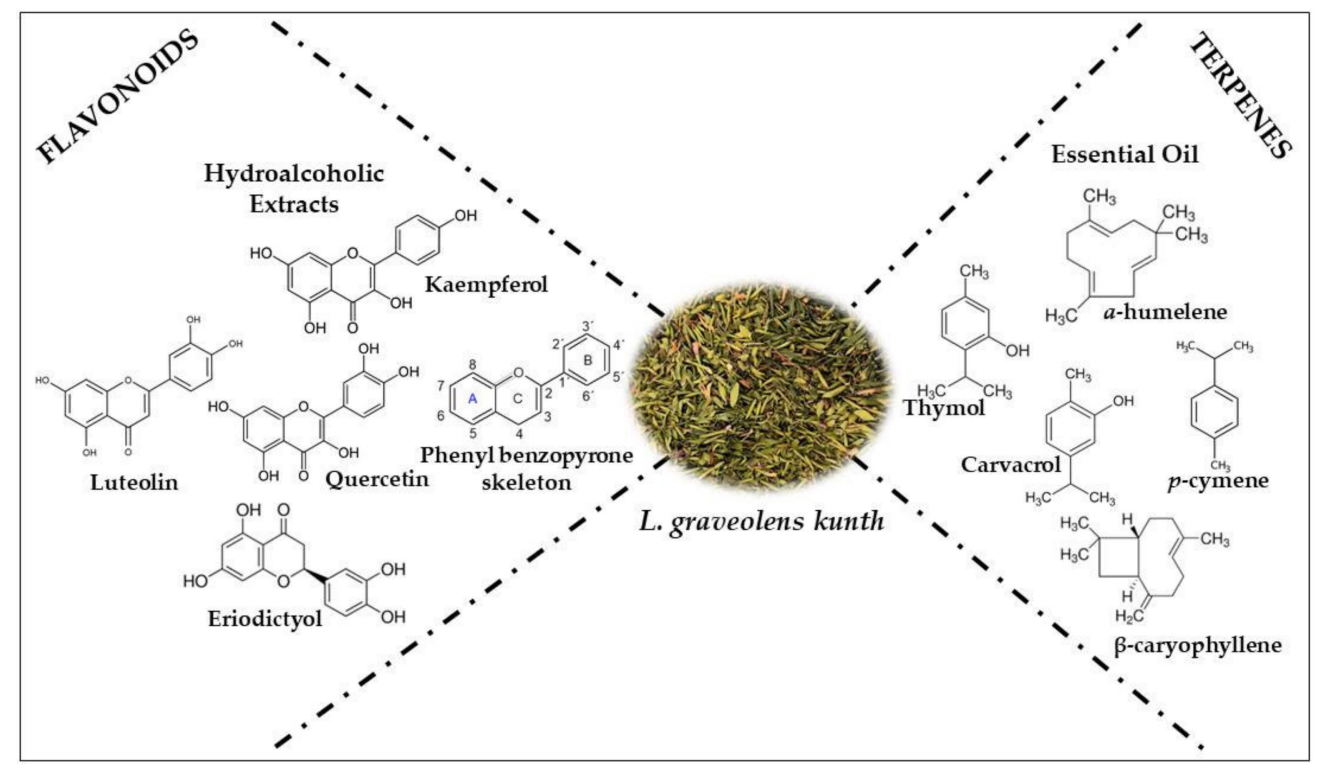

Figure 1. Chemical compounds present in L. graveolens Kunth crops.

\subsection{Essential Oils (EOs)}

The key fraction of metabolites of interest in oregano plant consists of essential oils (EOs), which have high volatility at room temperature and pressure and are composed of aromatic compounds, among other metabolites (e.g., esters, alcohols, aldehydes, and hydrocarbons) [16,17]. The compounds found primarily in EOs are terpenes (monoterpenes and sesquiterpenes) that are responsible for the aroma of aromatic plants; they are members of the mevalonate-based pathway active in the cytosol and are not dependent on 
mevalonate 2-C-methyl-D-erythriol 4-phosphate. Monoterpenes $\left(\mathrm{C}_{10} \mathrm{H}_{16}\right)$ are composed of a 10-carbon chain that can be alicyclic, monocyclic, or bicyclic and contain unsaturated hydrocarbons and/or functional classes (e.g., alcohols). Sesquiterpenes $\left(\mathrm{C}_{15} \mathrm{H}_{24}\right)$ are a more complex group of terpenoids since they can have a lactone ring and come in several forms such as linear, monocyclic, bicyclic, and tricyclic [18]. The composition and concentration of the metabolites found in EO vary according to the species studied. In the case of oregano, thymol and carvacrol are observed as main compounds, both with bioactive potential on human body and against industrially relevant microorganisms. Cid-Pérez et al. [19] identified the major chemical components (Table 1) present in EOs from Mexican oregano leaves (specifically P. longiflora), with thymol and carvacrol being the major compounds (1.97 \pm 0.05 and $0.89 \pm 0.10 \mathrm{mg} \mathrm{mL}^{-1}$, respectively). Similarly, previous studies using European varieties have revealed the presence of these compounds, with thymol having the highest proportion followed by carvacrol $[20,21]$. The EO extraction yield for oregano species varies, according to the literature $0.30-4.70 \%$ ). This is dependent on the tissue, the culture conditions, the oregano species, and the extraction process (technology and conditions) [2,22-24].

Table 1. Main compounds identified in L. graveolens and other Mexican oregano species.

\begin{tabular}{|c|c|c|c|c|c|c|}
\hline \multirow[b]{2}{*}{ Fraction } & \multirow[b]{2}{*}{ Species } & \multirow[b]{2}{*}{ Type of Isolation } & \multirow[b]{2}{*}{ Mainly Identified Compounds } & \multicolumn{2}{|c|}{ Content } & \multirow[b]{2}{*}{ Reference } \\
\hline & & & & $\begin{array}{c}\text { Concentration } \\
\text { (mg mL }{ }^{-1} / \mu \mathrm{g} \mathrm{mg}^{-1} \text { Extract) }\end{array}$ & $\%$ EO & \\
\hline \multirow{4}{*}{ Phenolic extracts } & L. graveolens & $\begin{array}{l}\text { Solid: liquid } \\
\text { (80\% methanol) }\end{array}$ & $\begin{array}{l}\text { Quercetin O-hexoside/ } \\
\text { Luteolin-glucuronide-glucoside/ Lithospermic } \\
\text { acid/Pentahydroxy dihydrochalcone derivative }\end{array}$ & - & - & [4] \\
\hline & L. graveolens & $\begin{array}{l}\mathrm{C}_{2} \mathrm{SCFE}\left(80 \mathrm{bar} 35^{\circ} \mathrm{C} /\right. \\
\left.\text { atmospheric } 20^{\circ} \mathrm{C}\right)\end{array}$ & $\begin{array}{l}\text { Eriodyctiol /Naringenin/ Sakuranetin/ } \\
\text { Cirsimaritin/ Chrysoeriol }\end{array}$ & $\begin{array}{c}4.9 \pm 0.2^{\mathrm{B}} / 4.6 \pm 0.2^{\mathrm{B}} / 3.1 \pm 0.29 \\
\mathrm{~B} / 2.34 \pm 0.04^{\mathrm{B}} / 1.3 \pm 0.1 \mathrm{~B}\end{array}$ & - & [15] \\
\hline & L. graveolens & $\begin{array}{l}\text { Solid: liquid } \\
\text { (methanol/acetone/water) } \\
\text { (50:40:10) }\end{array}$ & $\begin{array}{l}\text { Quercetin-O-hexoside/ Scutellarein } \\
\text { 7-O-hexoside/ Phloridzin/ } \\
\text { Trihydroxy-methoxyflavone } \\
\text { derivative/ 6-O-Methylscutellarein }\end{array}$ & - & - & [25] \\
\hline & L. graveolens & $\begin{array}{l}\text { Solid: liquid 1:20 (58\% } \\
\text { ethanol) }\end{array}$ & $\begin{array}{c}\text { Pinocembrin/Galangin/ phlorizin/ } \\
\text { Naringenin/Quercetin/ Hispidulin/ Taxifolin }\end{array}$ & $\begin{array}{r}3.231 \pm 0.390 \mathrm{~A} / 3.231 \pm 0.390 \\
\mathrm{~A} / 3.231 \pm 0.390 \mathrm{~A} / 3.231 \pm 0.390 \\
\mathrm{~A} / 0.018 \pm 0.008 \mathrm{~A} / 0.022 \pm 0.003 \\
\mathrm{~A} / 0.022 \pm 0.003 \mathrm{~A}\end{array}$ & & [26] \\
\hline \multirow{4}{*}{ Essential oil } & L. berlandieri & Commercial & $\begin{array}{c}p \text {-cymene/Carvacrol/ } \\
\beta \text {-pinene/Caryophyllene/Camphene/ } \\
\alpha \text {-pinene }\end{array}$ & - & $35.54 / 26.86 / 4.69 / 4.50 / 4.10 / 3.89$ & [13] \\
\hline & P. longiflora & Clevenger-type apparatus & $\begin{array}{c}\text { Carvacrol/ Thymol acetate/ Carvacrol, methyl } \\
\text { ether/ Terpinolene/ } p \text {-cymene/ Borneol/ } \\
\beta \text {-pinene }\end{array}$ & - & $\begin{array}{c}23.31 / 17.06 / 7.81 / 6.96 / 6.7 / 4.36 / \\
3.57\end{array}$ & [19] \\
\hline & L. graveolens & Hydro-distillation & $\begin{array}{c}\text { Different chemotypes } \\
\text { Carvacrol/ Thymol/ } \beta \text {-caryophyllene }\end{array}$ & - & $53.05 / 70.6 / 27.6$ & [27] \\
\hline & L. graveolens & Commercial & $\begin{array}{c}\text { Thymol/ } p \text {-cymene / Carvacrol/ } \\
\beta \text {-caryophyllene } / 1,8 \text {-Cineole } / \gamma \text {-terpinene }\end{array}$ & - & $31.66 / 18.72 / 14.57 / 5.62 / 3.44 / 2.42$ & [28] \\
\hline
\end{tabular}

The letter means: $\mathrm{A}=\mathrm{mg} \mathrm{mL}^{-1}$ extract, $\mathrm{B}=\mu \mathrm{g} \mathrm{mg}^{-1}$ extract and $\% \mathrm{EO}=$ Concentration on essential oil.

Even though thymol and carvacrol are the most abundant compounds in L. graveolens essential oils, there are other compounds (Table 1) that are significant, such as $\beta$ caryophyllene, $p$-cymene, $\alpha$-humelene, caryophyllene oxide, 1,8-Cineole, $\gamma$-Terpinene, and others [15,27-29]. The terpene and cannabinoid compound $\beta$-caryophyllene has significant anti-inflammatory potential and has been studied as a potential inhibitor of cellular proliferation $\left(10 \mu \mathrm{g} \mathrm{mL}^{-1}, 72 \mathrm{~h}\right)$ in glioblastoma through the interaction of CB2 and peroxisome proliferator-activated receptor gamma (PPARg) receptors [30]. Similarly, caryophyllene oxide is a sesquiterpene derived from various EOs [31]. It has been linked to antifungal and inflammatory properties [32,33]. Chavan et al. [33] reported its anti-inflammatory potential using a carrageenan-induced paw edema model; after three hours of the application of caryophyllene oxide ( $12.5 \mathrm{mg} \mathrm{k}^{-1}$ body weight) the volume of paw edema was statistically lower $\left(0.45 \pm 0.028 \mathrm{~mL},{ }^{*} p<0.05\right)$ than the control (Aspirin, $100 \mathrm{mg} \mathrm{k}^{-1}$ bodyweight) with $0.65 \pm 0.064 \mathrm{~mL}$. Otherwise, $p$-cymene and $\alpha$-humelene ( $\alpha$-caryophyllene) are monoterpenes and sesquiterpenes, respectively. The compounds have demonstrated varying bioactivity as an adjunct against inflammatory, cancer, and microbial ailments $[34,35]$. Oliveira et al. [36] also conducted an in vivo study that demonstrated $p$-cymene potential against gastric lesions. The data suggested that $p$-cymene and rosmarinic acid 
(50-200 mg kg ${ }^{-1}$ ) significantly decreased the ulcer area; the findings could be attributed to antioxidant and immunomodulatory properties.

Otherwise, the main components of oregano have been reported against medical relevant viruses, with carvacrol reportedly showing antiviral potential against HRSV (human respiratory syncytial virus) and RV (human rotavirus), the data reported that the chemical application (pre/post-viral inoculation) showed a $\mathrm{EC}_{50}$ value between 55.9 to $123 \mu \mathrm{g} \mathrm{mL}^{-1}$ [37]. Additionally, carvacrol and thymol were reportedly shown to inhibit HIV-1 replication ( $\mathrm{IC}_{50}$ value: $16 \pm 2.9 \mu \mathrm{M}$ and $25.2 \pm 4.9 \mu \mathrm{M}$ ), cholesterol depletion of viral membrane and a blocking viral fusion on the HIV-1 virus [38,39].

Finally, the bioactivities associated with oregano EO are mostly relevant to the health and food sectors, although there have been reports of applications as an auxiliary in agronomic aspects such as green pesticides. The most important examples of EO application can be found in a study conducted by Cui et al. [8], in which the OEO was tested against Methicillin-Resistant S. aureus or MRSA, and studies conducted in 2017 have shown promising results in the application of oregano $\mathrm{EO}(\mathrm{O}$. vulgare) in combinations with other oils (Syzygium aromaticum "cloves" and Leptospermum scoparium "manuka") as a larvicidal agent against Aedes aegypti [40].

\subsection{Polyphenolic Compounds (PCs)}

Peoples are interested in oregano plants because of their possible use as auxiliaries in a variety of applications. Polyphenolic compounds (PCs) are the second most common category of compounds in nature, only second to cellulose, which includes a wide range of compounds with at least one aromatic unit or phenol and one group hydroxyl, with a general classification corresponding to flavonoids and non-flavonoids [41]. PCs in plants perform protective functions against both abiotic (UV radiation) and biotic (pathogens, herbivores, and insects), which has led to research into the potential of compounds as adjunct agents in oxidative processes involved in the health and food sectors, as well as antimicrobial activities against strains of interest [42-44]. Flavonoids are the PCs with the highest bioactivity and are thought to be health boosters and preventive supplements with high nutritional and therapeutic value. This group has a phenyl benzopyrone skeleton, which is made up of two phenyl rings (A and B) connected by a pyran ring. Similarly, the methylation and hydroxylation found in rings A and B vary between the different flavonoid families. Flavones, isoflavones, flavonols, and anthocyanins are examples of flavonoid compounds [41]. Non-flavonoids, on the other hand, are compounds with a diverse structure that can include complex structures with high molecular weight. The group's main representative is phenolic acids, which are composed of a phenyl group, a carboxylic functional group, and one or more hydroxyl. These compounds are classified as hydroxybenzoic acids $\left(\mathrm{C}_{6}-\mathrm{C}_{1}\right)$ and hydroxycinnamic acids $\left(\mathrm{C}_{6}-\mathrm{C}_{3}\right)$, with the former corresponding to an aromatic ring, a carboxylic group and one or more hydroxyl, while the latter indicates the existence of an additional chain with a double bond $(\mathrm{C}=\mathrm{C})$ and the carboxylic group [41,42].

The bioactivities related to oregano plant material extracts could be the result of the presence of phenolic compounds (flavonoids and phenolic acids) [44-46]. Cid-Pérez et al. [19] discovered the presence of phenolic acids (caffeic acid and rosmaric acid) P. longiflora residues. Similarly, compilation works (Table 1) of the most recent studies on oregano species have highlighted the existence of flavonoids and phenolic acids primarily glycosylated in plant tissues, such as luteolin, kaempferol, quercetin, eriodyctiol, naringenin, caffeic acid, gallic acid, and others $[4,15,25,26]$.

A relevant bioactive compound present in L. graveolens extracts such a galangin has been shown to have antimicrobial, antimutagenic, antioxidant, anti-inflammatory, skin protector, and antiproliferative potential [47]. Hesperidin, another important compound, has been shown to have a possible auxiliary effect against fibrosis and hepatic oxidative stress by increasing hepatic antioxidant response [48]. Similarly, the use of naringenin potential against hepatotoxicity has been studied, and the results indicate a reduction 
in lipid oxidation, stabilization of the antioxidant response, and tissue protection [49]. The lithospermic acid and lithospermic acid B isolated from Salvia miltiorrhiza were found to be efficient and selective integrase inhibitors (IIs) on in vitro antiviral studies [50]. Otherwise, phenolic compounds, such as sakuranetin, present in Mexican oregano species have been previously isolated from Baccharis retusa $D C$, and it showed antileishmanial potential against protozoa of the genus Leishmania (L. amazonensis and L. braziliensis) with $\mathrm{IC}_{50}$ values of 51.89 to $45.12 \mu \mathrm{g} \mathrm{mL}{ }^{-1}$, respectively [51]. Similarly, given the material's richness, the study of the residual material of the essential oil fraction is important, as the material is rich in other compounds of interest that can promote product added value.

\subsection{Oregano by-Products a Source of Polyphenolic Compounds}

The extraction techniques are primarily concerned with the acquisition of targeted molecules (EOs), which constitute most industry's economic profits. Otherwise, the residual material is discarded, a by-product problem occurs because of the large residual volume caused by the lower EOs extraction percentage (1-3\%), the high generation of food waste presents potentially serious contamination problems, and high handling costs [52]. Mendez-Tovar et al. [53] identified that using by-products for energy generation or composting is a popular alternative, but the residual compounds may have antibacterial properties.

Furthermore, the residual material can be a rich source of bioactive compounds [15,19]. The by-products of L. graveolens are a rich source of bioactive compounds that could be valorized to increase the economic income of Mexican farmers. Arias et al. [15] identified 13 flavonoid compounds in L. graveolens by-products, highlighting the existence of apigenin, pinocembrin, galangin, and other compounds with well-studied bioactivities. Similarly, the value of O. vulgare ssp. hirtum residual material was assessed, and the key components of the hydro-alcoholic extract were rosmarinic acid, lithospermic acid, and glycosides flavonoids [54]. The residual extracts could be labeled as by-products; additionally, the residual extracts by microwave-assisted hydrodistillation (MAHD) revealed chlorogenic acid, caffeic acid, and luteolin-7-O-glucoside as the key components for $O$ vulgare. Similarly, caffeic acid and rosmarinic acid have been found in Mexican oregano (P. longiflora) [19].

\section{Extraction Techniques}

The extraction process, which allows to recover a particular fraction that, after purification, can be applied to a food commodity (functional food market), is a critical step in exploiting the potential additional values of bioactive compounds $[55,56]$. Furthermore, the market increases the quest for improved extraction methods with lower operating costs and environmental friendliness by reducing organic solvent (hexane, chloroforms, ethyl acetate, etc.) in addition to a lower energy intake without compromising the consistency and quantity of the desired molecules (chemical structure stability) [57-59]. The following techniques (Figure 2) comprise current extraction procedures to recover secondary metabolites or those with potential application in Mexican oregano species. 


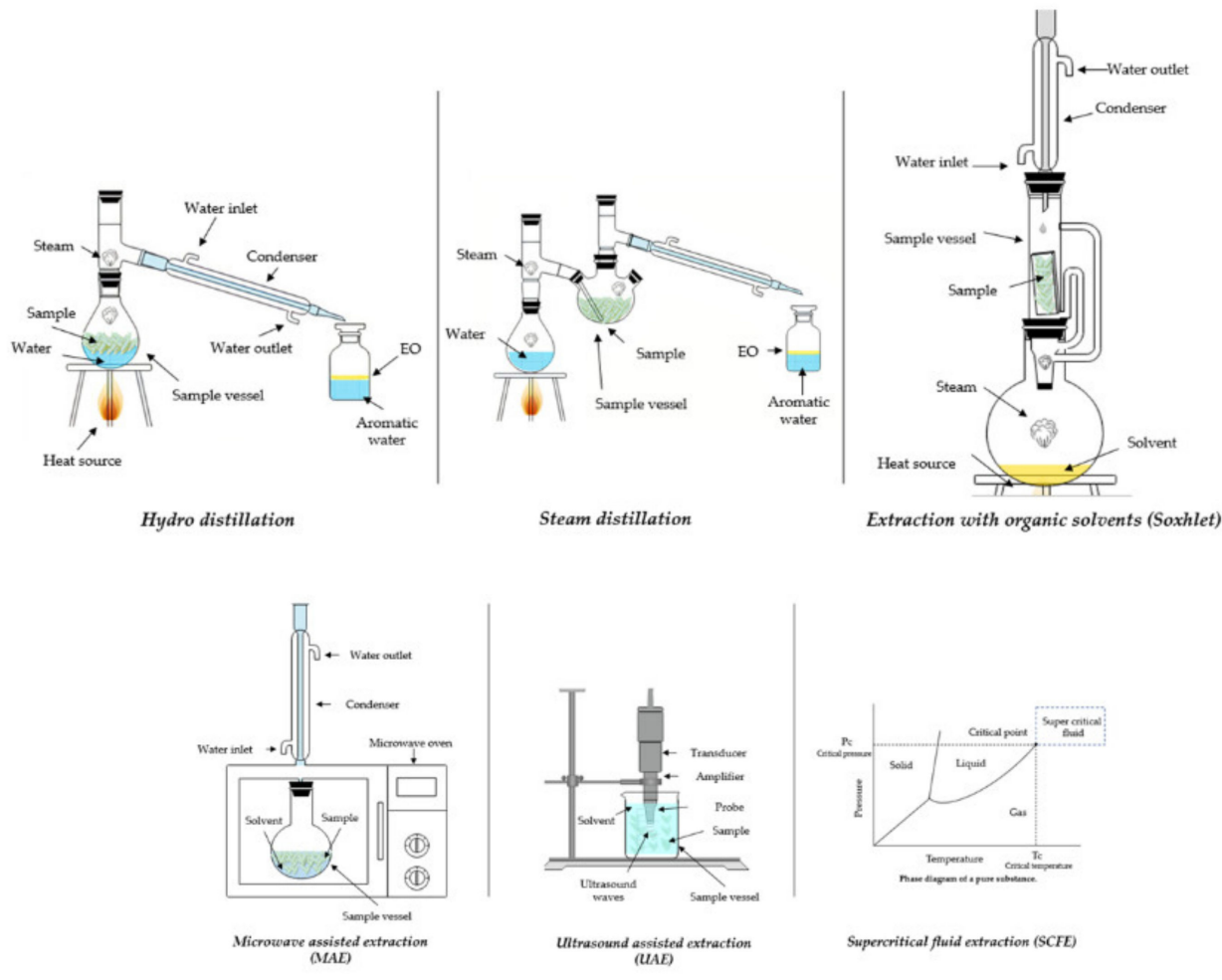

Figure 2. Extraction technologies applied in the recovery of secondary metabolites of Mexican oregano species [MAE: Microwave-assisted extraction; UAE: Ultrasound-assisted extraction; SCFE: Supercritical fluid extraction].

\subsection{Conventional}

\subsubsection{Hydrodistillation}

Hydrodistillation (HD) is a conventional and simple process for EO extraction that is used all over the world. Its applications include clove (Syzygium aramaticum), lavender (Lavandula officinalis), laurel (Laurus nobilis), oregano varieties, and other aromatic plants [60]. The plant material is immersed in boiling water as part of the technology (Figure 2). Following that, the emitted steam is directed to a condenser/separator to collect and isolate the EO from the water. Decantation is used in the separation process to increase the hydrophobicity of the EO. The HD process produces two by-products: residual water or aromatic waters "hydro-extract" and waste plant material. According to Cinbilgel et al. [61], residual water from EO processing was previously used in the subsequent extraction process, but it is now being sold as a commercial commodity by some oregano producers in Turkey. In addition, the reduced activity of HD-extracts from other plants for the bioreduction of $\mathrm{Pd}(\mathrm{II})$ to $\mathrm{Pd}(0)$ nanoparticles has been stated [62]. The application of HD in oregano crops mainly involves a long time extraction process $(1-4 \mathrm{~h})$ with large amounts of water; also, it is important to highlight that the extraction yield can be affected by steam flow [2]. The HD technology englobes an extraction yield range for Mexican oregano from $1.95 \pm 0.15 \%$ to $2.26 \pm 0.12 \%$ $v / w$ [1]. Otherwise, in a recent year, the search of new "greener" ways to metabolites recovery on oregano species has proposed the Ohmic Heating-Assisted Hydrodistillation $(\mathrm{OAH})$; the $\mathrm{OAH}$ comprises a lower extraction times with non-significance differences $(p>0.05)$ between extraction yield against HD with similar antioxidant activity [63].

The benefits of HD technology include a quick and easy-to-handle operation, as well as the capacity of water being immiscible with the essential oil fraction, which facilitates separation. Otherwise, the drawbacks include a long operating time (between 1 and $24 \mathrm{~h}$ ), polar molecule losses, and chemical changes caused by interaction with boiling temperatures $[64,65]$. 


\subsubsection{Steam Distillation}

Steam distillation (SD) refers to a group of methods that use steam as an extraction agent in hydrodistillation. The distinction between steam distillation and previous technologies is that there is no interaction between the plant material and water in steam distillation. SD may also be defined as direct or dry. In the direct phase, the target material is assisted in the same apparatus with water at the bottom that is heated to produce steam, and the volatile compounds are carried by the steam where they are diffused. Otherwise, in the dry phase, steam is produced in a separate (Figure 2) outside boiler and transported via plant material [66]. Some advantages include a solvent-free extraction, a low-cost operation, simple handling technology, and no subsequent separation steps. Furthermore, the distance between the steam generator and the target material has the benefit of minimizing EO variations [67]. The SD technology englobes an extraction yield range for Mexican oregano from $0.92 \%$ to $4.41 \% v / w$ [2,19]. In addition, the OEOs recovered by SD and HD have a similar chemical composition with thymol, carvacrol and cymene isomers as main components $[1,2,19,63]$.

\subsubsection{Extraction with Organic Solvents}

The process (Figure 2) employs organic solvents (chloroform, methanol, hexane, ethyl acetate) for compound extraction, allowing that the extraction takes place at lower temperatures and preventing the alterations (e.g., hydrolysis, deprotonations, etc.) caused by high temperatures compared to the previous methodologies. The drawback of its implementation is the residual contaminating material, which jeopardizes product protection $[64,67]$. Further, the organic solvents in Mexican oregano studies have been used to obtain a terpene fractionation (methanol, chloroform, and acetone) with an evaporation step [25]. The risk of organic solvent application was explored in the evaluation of L. graveolens organic extracts (hexane) on male CD-1 mice with a $\mathrm{LD}_{50}: 1000 \mathrm{mg} \mathrm{kg}^{-1}\left(\mathrm{LD}_{50}=\right.$ Lethal Dose 50\%) [68].

\subsection{Emerging Technologies}

\subsubsection{Ultrasound-Assisted Extraction (UAE)}

Ultrasound-assisted extraction is a new technique that has significant advantages over its traditional predecessors, such as not requiring high operating temperatures, a lower degree of difficulty, no hazardous waste, high efficiency, and increased the quality of the targeted molecules $[65,69,70]$. Mohammadpour et al. [70] compared secondary metabolite extraction methods using Soxhlet (Conventional) against UAE in Moringa peregrina, and the results showed an improvement in the evaluated bioactivity (DPPH• and total phenols). The authors concluded that the UAE approach improves extraction efficiency. The technology (Figure 2) consists in the use of acoustic energy in conjunction with appropriate solvents to extract targeted molecules from plant matrix, the formation of bubbles due to cavitation phenomena, and their implosion results in a shear force that splits the cell, allowing compounds to be released into the extracting solvent [64,71]. The UAE has been used in oregano species for metabolite recovery; Oreopoulou et al. [54] reported a kinetic study of the phenolic compounds extraction process on oregano (Origanum vulgare ssp. hirtum) by-product of EO extraction process, the experimental data suggest a higher recovery of polyphenols using: $60 \%$ ethanol: water, particle size $<600 \mu \mathrm{m}$, temperature $22{ }^{\circ} \mathrm{C}$ and a solid: liquid ratio of 1:20 under the specifications of the extraction system used. L. graveolens extracts obtained by UAE have been applied on active packaging for blackberries with resveratrol, catechin and luteolin as identified compounds [72].

\subsubsection{Microwave-Assisted Extraction (MAE)}

Microwave-assisted extraction is a novel technology that combines conventional solvent extraction with microwave (Figure 2) energy for bioactive compound extraction from plant matrix using magnetic and electrical fields with frequency ratios ranging from $300 \mathrm{mHZ}$ to $300 \mathrm{GHz}$ [73]. The energy system offers two mechanisms for molecular motion: ion migration and dipole rotation [74]. The technology involves a detachment between 
solute and active sites in the sample matrix under high energy conditions (temperature and pressure), followed by a solvent diffusion through the matrix and the matrix releasing the targeted compounds into the solvent $[75,76]$. Applications of MAE have advantages such as a low-temperature gradient (targeted heating), quicker curing times, better extraction yields, smaller facilities, and the ability to use "green" solvents instead of organic solvents (chloroforms, hexane, etc.). The microwave efficiency is highly dependent on solvent and matrix properties (dielectric constants) and combining a certain solvent with a plant matrix can increase extraction and procedure consistency. According to Llompart et al. [74], there is an unusual mechanism suitable for thermolabile compounds in which only the sample matrix is heated, and the solutes are released into the cold solvent. The MAE technology has been applied in other oregano species as $O$. vulgare for EO recovery by Microwave-assisted hydro-distillation (MAHD) with higher recovery yields (2.55\%-7.10\%) compared to $5.81 \%$ for HD [77].

\subsubsection{Supercritical Fluid Extraction (SCFE)}

As an alternative to traditional methods, supercritical fluid extraction (SCFE) technology has been used in recent years for the extraction of bioactive compounds in complex matrices. As extraction agents, the SCFE used fluids at or above (Figure 2) supercritical temperatures and pressures [78-82]. Since supercritical fluids share properties with liquids and gases (density like liquids and viscosity like gases), they can penetrate deeper and faster into the matrix [83-85]. Supercritical $\mathrm{CO}_{2}$ is often used due to its chemical properties (critical point $7.38 \mathrm{MPa}$ and $304.2^{\circ} \mathrm{K}$ ) as well as its safety (non-toxic). Furthermore, the solvent creates a non-oxidizing extraction environment. The benefits include a green and sustainable technology, lower energy requirements, low-temperature operation, higher extraction yields, strong selectivity, solvent recycling, and higher efficiency of targeted molecules $[65,66,79-82,86,87]$. Instead of molecules with low thermal stability that could be compromised by traditional thermal technology, the SCFE offers a safer alternative to bioactive compound extraction.

The general procedure consists of two stages: (i) extraction and (ii) extract isolation from the solvent. The supercritical fluid absorbs the solute in the first step (convection and diffusion). Following that, the pressure is decreased, as is the solvent strength, precipitating the solute (stage 2) $[66,79-82,84,88]$. To greatly improve the extraction performance of polar materials, a cosolvent (ethanol and methanol) can be used [83]. The SCFE application has been studied on L. graveolens by-products for flavonoid recovery using an optimization factorial design with extraction variables (pressure, temperature, flow, particle size, extraction time and ethanol percentage) [89].

\subsection{Chemical Variation of Extraction Techniques}

Because plant material and targeted compounds are subjected to various extraction conditions (EC), the choice of an extraction process has a significant effect on the chemical structure of the plant extract and the bioactivity relevant to phytochemical compounds (temperature, pressure, solvent, and others). Otherwise, the EC will have an impact on the density and solubility of the extraction fluid [89]. Similarly, other ECs such as solvent concentration, particle size, plant: solvent ratio, and temperature have been stated to have a significant impact on bioactive oregano extracts. For example, the extraction selectivity for polyphenolic compounds (\%) with respect to temperature in oregano plants was higher before $40{ }^{\circ} \mathrm{C}(25.22 \pm 0.42 \%)$ and decreased when the process reached $60{ }^{\circ} \mathrm{C}$ $(19.36 \pm 0.11 \%)$. According to the results, higher temperatures can cause thermal degradation of thermo-sensitive compounds [54]. Thus, the relationship between ECs and targeted material is critical in the recovery of bioactive compounds.

Several experiments have been conducted to determine the effect of extraction methods on plant extract bioactivity. García-Pérez et al. [90] investigated the statistical correlation and thermodynamics of supercritical- $\mathrm{CO}_{2}$ extraction in Mexican plants. The results indicated 
that the mixture of pressure and solvents influences antioxidant activity (expressed as radical $\mathrm{DPPH}^{\bullet}$ scavenging and FRAP assay).

There is some evidence indicating that the concentration of oregano EOs' key components could be responsible for bioactivity. Borgarello et al. [91] showed that residual fractions of OEO using molecular distillation had thymol concentrations up to 2.4 times greater than raw essential oil and higher antioxidant function. Similarly, a comparison of MAE and $\mathrm{HD}$ in OEO revealed a lower percentage of oxygenated monoterpenes (2.87-11.81\%) in HD extracts, which might be due to thermal and hydrolytic conditions in which oxygenated monoterpenes convert to hydrocarbon monoterpenes [77]. High temperatures can degrade heat-labile phenolic compounds or cause polymerization under high pressures [46]. For example, Ameer et al. [92] confirmed that temperature decreased hesperidin yield on citrus peel for a longer extraction process with elevated temperatures. It is worth noting that its aglycone type has also been identified as a flavonoid present in Mexican oregano species [44].

Finally, differences in chemical compounds and bioactivity associated with extracts have been identified in other aromatic plants. For example, Conde-hernandez et al. [93] demonstrated that antioxidant activity of Rosmarinus officinalis EOs obtained by various technologies (SCFE, SD, and HD) showed a bioactivity difference, with supercritical extraction resulting in 14 times more antioxidant activity than steam distillation and hydrodistillation. As a result, an extraction optimization approach can also be used to build a better process to ensure the chemical stability for most bioactive compounds as well as a green extraction.

\section{Bioactive Potential of Mexican Oregano Fractions}

The recovery of secondary metabolite fractions of plant content from oregano has been used in evaluations for their activity as an auxiliary in antioxidative and antimicrobial methods, inhibition, dietary supplementation, and the production of green pesticides (Figure 3 and Table 2).

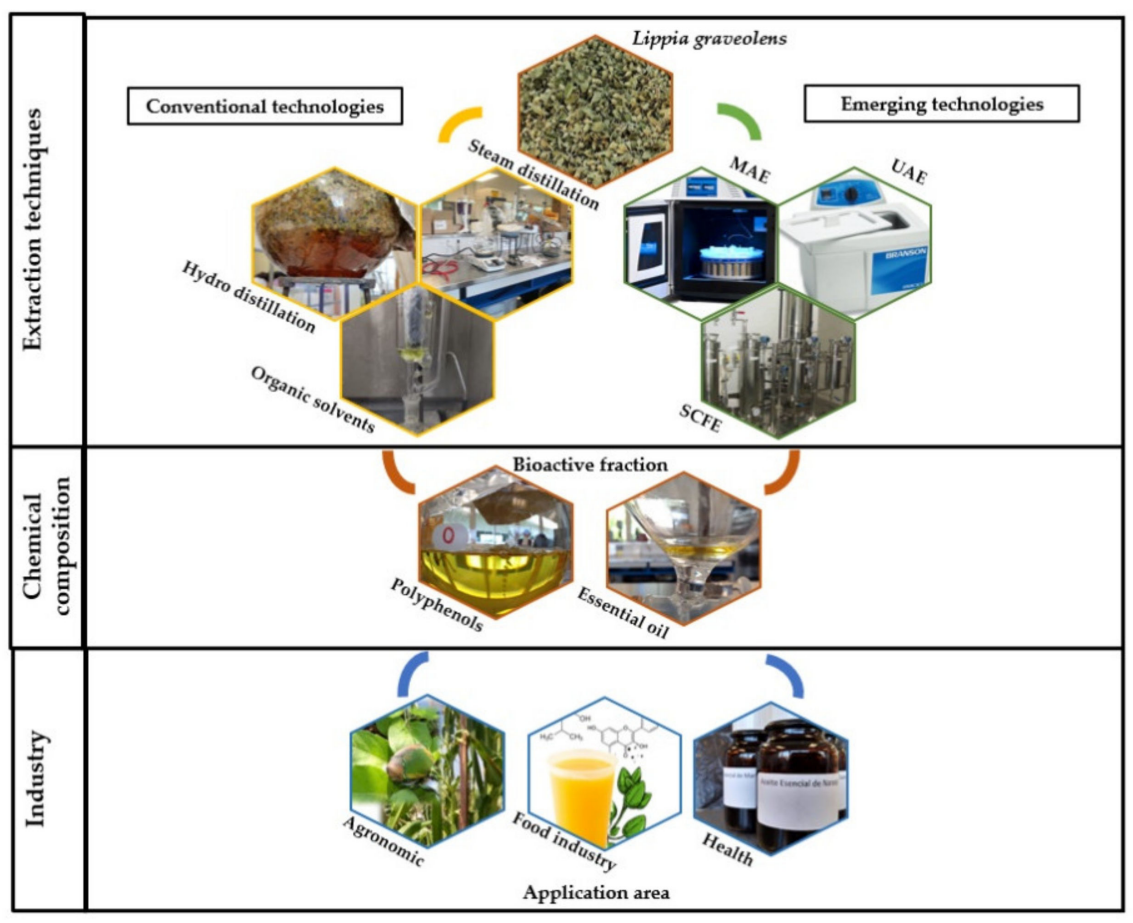

Figure 3. Extraction technologies, products, and application areas of Mexican oregano (L. graveolens). [MAE: Microwave-assisted extraction; UAE: Ultrasound-assisted extraction; SCFE: Supercritical fluid extraction]. 
Table 2. Evaluations of the bioactive potential in Mexican oregano.

\begin{tabular}{|c|c|c|c|c|c|c|c|}
\hline Specie & Analyzed Fraction & Extraction Technique & Tissue & \multicolumn{2}{|c|}{ Evaluated Bioactivity } & Results & Reference \\
\hline L. berlandieri & Essential oil & - & Leaves & Antimicrobial & E. coli/MRSA/A. niger & $\begin{array}{l}\text { 4/lower than } 5 / 0.28 \\
\text { (MIC, } \mu \mathrm{g} \mathrm{mL}^{-1} \text { of air) }\end{array}$ & [13] \\
\hline \multirow{2}{*}{ P. longiflora } & \multirow{2}{*}{$\begin{array}{c}\text { Essential oil } \\
\text { Et-OH extract } \\
\text { Ethyl acetate extract }\end{array}$} & \multirow{2}{*}{ Hydrodistillation/Diffusion } & \multirow{2}{*}{ Leaves } & Antioxidant activity & \multirow{2}{*}{$\begin{array}{c}\mathrm{DPPH}^{\bullet} \\
\text { S. aureus/B. cereus }\end{array}$} & $\begin{array}{c}83.70 \pm 4.12 \mathrm{EO}, 151.90 \pm 6.65 \\
\text { E-OH, } \\
208.60 \pm 12.25 \mathrm{Et}-\mathrm{Ac} . \\
(\mathrm{IC} 50, \mu \mathrm{g} \mathrm{mL}-1)\end{array}$ & \multirow{2}{*}{ [19] } \\
\hline & & & & Antimicrobial activity & & $\begin{array}{c}250 / 250 \mathrm{EO} \\
1000 / 750 \mathrm{E}-\mathrm{OH}, \\
750 / 500 \mathrm{E}-\mathrm{Ac} \\
(\mathrm{MIC}, \mathrm{mg} \mathrm{L}-1)\end{array}$ & \\
\hline $\begin{array}{l}\text { L. graveolens } \\
\text { L. palmeri }\end{array}$ & $\begin{array}{l}\text { Chloroform/ } \\
\text { methanol extracts }\end{array}$ & Agitation/Sonication & Leaves & Antiflammatory & $\begin{array}{l}\text { ROS reduction } \\
\text { COX-1 and } 2 \\
\text { cyclooxygenases } \\
\text { inhibition }\end{array}$ & $\begin{array}{c}59.8 \% \text { to } 87 \% \\
\text { COX-1 } \\
78.2 \% / 64.7 \% / 67.8 \% \\
\text { COX-2 } \\
81.7 \% / 74.6 \% / 64.7 \% \\
\end{array}$ & [25] \\
\hline L. graveolens & Essential oil & - & Leaves & Antimicrobial & Candida albicans & $\begin{array}{c}6.4 \text { to } 21.5 \\
\text { (MLC }{ }_{99}, \mu \mathrm{L} \mathrm{mL}^{-1} \\
\text { agent) }\end{array}$ & [28] \\
\hline L. graveolens & Methanolic extract & Maceration & Aerial parts & $\begin{array}{l}\text { Antioxidant } / \mathrm{UV} \\
\text { protection }\end{array}$ & $\begin{array}{l}\mathrm{DPPH}^{\bullet} \\
\text { In vivo penetration } \\
\text { study }\end{array}$ & $\begin{array}{c}21.89 \pm 0.63 \\
\left(\mathrm{IC}_{50, \mu \mathrm{gL}^{-1}}\right) \\
20.14 \pm 1.86 \\
\left(\mu \mathrm{g} \mathrm{cm}^{-2}\right)\end{array}$ & [94] \\
\hline \multirow{3}{*}{ L. graveolens } & \multirow{3}{*}{ Methanol extract } & \multirow{3}{*}{ Percolation } & \multirow{3}{*}{ Leaves/flowers } & Antiglycemic & $\alpha$-glucosidase inhibition & $\mathrm{IC}_{50}=37.19 \mu \mathrm{M}$ (Hispidulin). & \multirow{3}{*}{ [95] } \\
\hline & & & & Anti-inflammatory & Antiflammatory & $\begin{array}{c}\mathrm{IC}_{50}=0.72-1.31 \mu \mathrm{mol} / \mathrm{ear} \\
\text { (Naringenin, Eriodictyol and } \\
\text { 3-Hydroxyphloridzin). }\end{array}$ & \\
\hline & & & & Cytotoxicity & $\begin{array}{c}\text { U251 \& SK-LU-1 } \\
\text { human tumor cell lines. }\end{array}$ & $\begin{array}{c}\mathrm{U} 251 \\
\left(\mathrm{IC}_{50}=37.0 \mu \mathrm{M}\right) \\
\text { SK-LU-1 } \\
\left(\mathrm{IC}_{50}=37.5 \mu \mathrm{M}\right)\end{array}$ & \\
\hline
\end{tabular}

$\mathrm{EO}=$ Essential oil, $\mathrm{E}-\mathrm{OH}=$ Ethanol extract, $\mathrm{E}-\mathrm{Ac}=$ Ethyl acetate extract, $\mathrm{MIC}=$ Minimum Inhibitory Concentration, $\mathrm{MLC}=\mathrm{Minimum}$ Lethal Concentration, ROS = Reactive oxygen species, COX-1 = cyclooxygenase -1, COX-2 = cyclooxygenase- 2, U-251 MG cell line human, SK-LU-1: Human Lung Cancer Cell Line.

\subsection{Food}

The main use of oregano plants in the food industry is due to the organoleptic properties and flavoring properties in traditional foods. Recently, some investigations have explored the use of oregano fractions (EO or extracts) as a green auxiliary for food stability. For example, the antioxidant potential of L. graveolens extracts has been assessed (Table 2) using free radical scavenging methodologies such as DPPH• to elucidate the extracts' ability as reactive oxygen species scavengers (ROS). The observed $\mathrm{IC}_{50}$ values vary from $21.89 \pm 0.63$ to $208.60 \pm 12.25 \mu \mathrm{g} \mathrm{mL}^{-1}$, an interval that would be influenced by the fraction collected from the plant, since certain extractions performed favor the recovery of polar or non-polar compounds and report various bioactivities [19,94]. Similarly, P. longiflora plant classified as Mexican oregano was investigated by Lu-Martínez et al. [96] for P. longiflora EO fractions in Prunus seronite var. capuli (black cherry) oil as a natural source of antioxidants to have an extended life by slowing lipid oxidation. The findings indicated that a higher concentration $\left(>3000 \mathrm{mg} \mathrm{L}^{-1}\right)$ would induce pro-oxidation and a lower concentration $\left(3 \mathrm{mg} \mathrm{L}^{-1}\right)$ controls the formation of hydroperoxides. Similarly, the antioxidant ability of oregano as a lipid oxidation inhibitor has been investigated by its use in rich fatty acid beverages, with promising inhibition percentages (88-55\%) [97].

Moreover, the oregano plant contains a high concentration of bioactive compounds (thymol, carvacrol, and caryophyllene oxide), which have been linked to antifungal/ antibacterial properties and represent a green alternative for microorganism regulation of food-relevant strains. As an alternative, the use of OEOs could be a relevant approach, but the downside is that high volatilization can reduce process effectivity. The microemulsions should be used, and especially the oregano microemulsions demonstrated a lower MIC (Minimum Inhibitory Concentration) and MBC (Minimum Bactericide Concentration) by encapsulated EO of 2.25 and $4.5(v / v \%)$ for Listeria monocytogenes and Escherichia coli, respectively. Nonencapsulated EO, on the other hand, allowed a higher concentration of $9(v / v \%)[98]$.

Furthermore, food science in recent years has been focusing on the advancement of functional foods that have health benefits in addition to nutritional value. According to Gutierrez-Grijalva et al. [4], Mexican oregano (L. graveolens) can have significant potential as an auxiliary antioxidant and against enzymes involved in lipid and carbohydrate 
metabolism. However, their data indicate a difference depending on the digestion process, resulting in decreased activity for $\alpha$-glucosidase inhibition and increased activity for $\alpha$ amylase and lipase inhibition. The biomolecule heterogeneity in L. graveolens distinguishes the crop as a good source of bioactive compounds.

\subsection{Health}

Because of the rich bioactive fraction from plant extracts, the L. graveolens plant has been commonly used in traditional medicine as a strong auxiliary against certain ailments linked to microorganism infections or inflammatory processes. The main components of oregano extracts have been associated with the capability of bacterial control, including against antibiotic-resistant strains. Cui et al. [8] demonstrated the antibacterial activity of OEO against $S$. aureus (MRSA) and proposed a potential action mechanism that includes cell membrane disruption, negative respiratory chain interactions with main enzymes, carvacrol DNA interactions, and Panton Valentine leukocidin virulence factor (PVL) inhibition.

Furthermore, $P$. longiflora fractions (EO and hydroalcoholic extracts) have a MIC from 250 to $1000 \mathrm{mg} \mathrm{L}^{-1}$ against pathogenic bacteria such as Staphylococcus aureus and Bacillus cereus [19]. Furthermore, Reyes-Jurado et al. [13] evaluated the antimicrobial efficacy of essential oils (EOs) applied in the gaseous phase, the Lippia berlandieri assessment determined MIC values of 4 (Escherichia coli) and 0.28 (Aspergillus niger) $\mu \mathrm{g} \mathrm{mL} \mathrm{mL}^{-1}$ of air against relevant microorganism in the agricultural and food sectors. In addition, L. graveolens emulsion (Table 2) demonstrated an MLC $_{99}$ (Minimum Lethal Concentration) range of 6.4 to $21.5 \mu \mathrm{L} \mathrm{mL}^{-1}$ emulsifier agent for Candida albicans, a relevant opportunistic human pathogen that causes candidiasis disease [28].

Furthermore, research on Mexican oregano extracts has been expanded to regulate ROS-related disorders in the body, taking advantage of the plant's secondary metabolites with promising antioxidant potential. For L. graveolens, L. palmeri, and Hedeoma patens species, Leyva-López et al. [25] obtained positive findings in reducing the levels of ROS involved in inflammatory activities (59-87\%), as well as inhibition of up to $78.2 \%$ and $81.7 \%$ of cyclooxygenases 1 and 2, respectively. The cyclooxygenases 2 inhibition assay measuring by PGF2 $\alpha(\mathrm{ng} / \mathrm{mL})$ production applied as positive control DuP-607 (DUP, $50 \mathrm{nM}$ ), DUP showed a statistically lower PGF2 $\alpha$ concentration than oregano extracts. Furthermore, ethanolic extracts of $O$. vulgare are high in bioactive compounds such as rosmarinic acid, quercetin, apigenin, and carvacrol. Such bioactive compounds are also found in L. graveolens plants, which have been analyzed in terms of the inflammatory response by Propionibacterium acnes, demonstrating an inhibition of $32-37 \%$ of inflammation; the authors suggest that the obtained results could be the results of antimicrobial potential and a decrease in the related mRNA (messenger RNA) of interleukins involved in inflammatory processes such as IL-8 and IL-1 $\beta$ [99]. In another study, an analysis of secondary metabolite extraction, isolation and characterization revealed the bioactivity of the main flavonoids present in oregano extract, the higher inhibition of $\alpha$-glucosidase $\left(\mathrm{IC}_{50}\right.$ value of $37.199 \mu \mathrm{M}$ ) was obtained by Hispidulin. In addition, the anti-inflammatory potential was tested in an in vivo system and the activity (CD-1 mice) registered a $\mathrm{IC}_{50}$ range of 0.72 to $1.31 \mu \mathrm{mol} / \mathrm{ear}$ [97].

L. graveolens extracts have been evaluated as a possible protective agent against UV radiation (Table 2). The authors stated that using the extract decreased the lesions seen in laboratory rats exposed to UV radiation compared to the control group [94], and that it could have an anxiolytic effect in CD-1 mice based on experimental behavioral models. Accordingly, the crude extracts showed a similar effect as the reference drug diazepam $\left(0.1 \mathrm{mg} \mathrm{kg}^{-1}\right)$ [68]. Furthermore, it is also important to note that further research and information about anxiolytic properties in humans are needed. 


\subsection{Agronomic}

Oregano residue is a rich source of bioactive molecules with possible health benefits in human and animal models. Several research studies have also centered on O. vulgare use as an ingredient for broiler feed, with possible benefits such as improved feed intake and conversion, disease regulation, improved digestion, fewer commercial antibiotics, and a lower economic effect for farmers [100]. Hernández-Coronado et al. [101] investigated the effects of two Mexican oregano species (P. longiflora and L. berlandieri) in drinking water on broiler meat quality. The authors discovered that OEO inclusion improved meat quality, and the sensory results revealed that treatment with P. longiflora produced the most suitable meat. Similarly, Bauer et al. [102] performed a study to determine the potential of $O$. vulgare as an antimicrobial agent applied to a diet (chickens) as a protective agent of the intestinal microbiota against pathogenic species such as Proteus spp., Klebsiella spp., and Staphylococcus spp., the study observed substantial inhibition at concentrations of $2 \%(w / w)$.

Furthermore, the use of EOs as green pesticides provides a relevant use due to the detrimental effects of conventional pesticides on ecosystem equilibrium, human and animal health, and chemical toxicity. The EO extracted from L. origanoides (a Mexican oregano) had an $\mathrm{LC}_{50}$ value of $53.79 \mathrm{mg} \mathrm{L}^{-1}$ against a health-relevant insect known as Aedes aegypti (Diptera: Culicidae). In addition, the use of a combination of L. origanoides and $S$. glutinosa showed a potential synergistic effect with a lower $\mathrm{LC}_{50}\left(38.40 \mathrm{mg} \mathrm{L}^{-1}\right)$ [103]. Similarly, the larvicidal effect of the main OEO components (carvacrol and terpinene-4-ol) against Anopheles stephensi, A. subpictus, Culex quinquefasciatus and C. tritaeniorhynchus gave $\mathrm{LC}_{50}$ of $21.15-27.95 \mu \mathrm{g} \mathrm{mL} \mathrm{L}^{-1}$ and $43.27-54.87 \mu \mathrm{g} \mathrm{mL}^{-1}$ [104]. In contrast, the EOs of O. vulgare ranged from 67 to $84.93 \mu \mathrm{g} \mathrm{m}^{-1}$ [104].

Finally, Castilho et al. [105] investigated the agronomic tool of in vitro production for oregano plants, and the findings indicated that the addition of a plant growth regulator (Kinetin, $4.6 \mu \mathrm{M}$ ) yielded a greater number of compounds. Furthermore, the presence of indole-3-acetic acid (IAA) facilitates a high thymol and carvacrol content. As a result, agronomic in vitro production offers a modern method for higher quality plants with improved organoleptic and nutritional properties.

\section{Research, Innovation, and Technological Perspectives}

\subsection{Intellectual Property}

Several studies have evaluated the bioactive potential and chemical composition of Mexican oregano crops, but to elucidate the application of Mexican oregano in market products. World intellectual property databases such as Google Patents, a Google search engine that indexes patents, and PATENTSCOPE, a patent search tool from the World Intellectual Property Organization (WIPO), have been applied to search the technological growth in Mexican oregano beyond laboratory experiments.

According to the search made in Google Patents and WIPO-PATENTSCOPE (accessed March 29, 2021) using the keyword "Lippia graveolens", 27 patents were registered in a period between 2004-2021. Of note, on Table 3 only seven patents use oregano in the formulations, two patents classified "oregano" as one of the main components in the formulation without a specific species. The patent ES2678597 is for a product made by a mixture of smokable herbs, which could be used as an auxiliary on smoking cessation, and it helps to clean and regenerate the lungs of the tobacco smoker [106]. The food technology patent (ES2613240) is focused on extending the shelf life of food by the creation of ice with antimicrobial activity by frozen drinking water and inclusion complexes formed by essential oils that are nano encapsulated with cyclodextrins. According to the technology, the melting ice will release bioactive compounds with antimicrobial activity [107]. 
Table 3. Reported patents in Google Patents and WIPO-PATENTSCOPE databases related with industrial application of oregano and Mexican oregano (L. graveolens).

\begin{tabular}{|c|c|c|c|c|c|c|}
\hline $\begin{array}{c}\text { Patent } \\
\text { Number }\end{array}$ & Title & Main Core & Scope & Publication Data & Country & References \\
\hline ES2678597 & $\begin{array}{l}\text { Smokable remedial herb } \\
\text { blend }\end{array}$ & $\begin{array}{l}\text { The present invention refers to a } \\
\text { mixture of smokable herbs, which } \\
\text { are part of a method of smoking } \\
\text { cessation and help to clean and } \\
\text { regenerate the lung of the tobacco } \\
\text { smoker. }\end{array}$ & Health & 14 August 2018 & Spain & [106] \\
\hline ES2613240 & $\begin{array}{l}\text { Composition of ice with } \\
\text { antimicrobial activity, } \\
\text { manufacturing method, } \\
\text { and its applications. }\end{array}$ & $\begin{array}{l}\text { The invention comprises a solution } \\
\text { of frozen drinking water and } \\
\text { inclusion complexes formed by } \\
\text { essential oils nano encapsulated } \\
\text { with cyclodextrins. }\end{array}$ & Food technology & 23 May 2017 & Spain & [107] \\
\hline ES2351116 & $\begin{array}{l}\text { Antimicrobial } \\
\text { therapeutic } \\
\text { compositions and } \\
\text { procedures for use. }\end{array}$ & $\begin{array}{l}\text { The present invention relates to an } \\
\text { injectable solution containing } \\
\text { isolated carvacrol and thymol of } \\
\text { natural origin for intramuscular or } \\
\text { intravenous administration. }\end{array}$ & Health & 31 January 2011 & Spain & [108] \\
\hline $\begin{array}{c}\text { MXNL/A/ } \\
\text { 2006/000057 }\end{array}$ & $\begin{array}{l}\text { Natural compounds } \\
\text { having antimicrobial } \\
\text { activity for preventing } \\
\text { and controlling } \\
\text { infectious diseases in } \\
\text { humans and food. }\end{array}$ & $\begin{array}{l}\text { The present invention refers to the } \\
\text { use of water-soluble extracts in } \\
\text { different concentrations of Larrea } \\
\text { tridentata added with other natural } \\
\text { products such as extracts and } \\
\text { essential oils of the leaves of } L \text {. } \\
\text { graveolens and other plants known to } \\
\text { have an antimicrobial effect }\end{array}$ & Health & 15 August 2006 & Mexico & [109] \\
\hline ES2628278 & $\begin{array}{c}\text { Biostimulant } \\
\text { formulation of plant } \\
\text { growth and } \\
\text { development and } \\
\text { inducer of resistance for } \\
\text { the control of diseases } \\
\text { caused by } \\
\text { phytopathogenic viruses } \\
\text { and method of } \\
\text { preparation. }\end{array}$ & $\begin{array}{l}\text { The biostimulant formulation is } \\
\text { composed of extracts, vegetable oils } \\
\text { from varieties of Chihuahuan } \\
\text { semi-desert plants, absolute oils, } \\
\text { and extracts from aromatic plants. }\end{array}$ & $\begin{array}{l}\text { Agricultural } \\
\text { biotechnology }\end{array}$ & 2 August 2017 & Spain & [110] \\
\hline MX365079 & $\begin{array}{l}\text { Process for the } \\
\text { regeneration of Mexican } \\
\text { oregano plants (of the } \\
\text { genus Poliomintha) by } \\
\text { indirect organogenesis. }\end{array}$ & $\begin{array}{l}\text { The invention refers to a process for } \\
\text { the in vitro regeneration of Mexican } \\
\text { oregano (Poliomintha genus), which } \\
\text { allows a complete plant to be } \\
\text { obtained from an explant. }\end{array}$ & $\begin{array}{l}\text { Agricultural } \\
\text { biotechnology }\end{array}$ & 28 February 2014 & Mexico & [111] \\
\hline MX2017013652 & $\begin{array}{l}\text { Method to increase the } \\
\text { secondary metabolites in } \\
\text { candelilla and oregano. }\end{array}$ & $\begin{array}{l}\text { The present invention relates to a } \\
\text { method for increasing the secondary } \\
\text { metabolites in crops such as } \\
\text { candelilla and oregano by abiotic } \\
\text { stressing. }\end{array}$ & Agronomic & 24 October 2019 & Mexico & [112] \\
\hline
\end{tabular}

Otherwise, four patents were directly related to the application of L. graveolens into the commercial product. The patent ES2351116 is comprised of an injectable solution containing isolated carvacrol and thymol of natural origin and anesthetic component to avoid discomfort; the application is via intramuscular or intravenous administration for use in human and veterinary medicine [108]. Similarly, the patent MXNL/A/2006/000057 belongs to health field in the application of Larrea tridentata extracts enriched with EOs from L. graveolens and medicinal plants with antimicrobial effects in humans and food models [109].

The following patents (Table 3 ) are related to the agronomic industry as biostimulants (ES2628278) that increase plant growth as a resistance inducer for the control of diseases caused by phytopathogenic viruses [110]. This includes an in vitro process (MX365079) for the regeneration of Mexican oregano (Poliomintha genus), which allows for sustainable agriculture schemes to be applied to this species, safeguarding the genetic material and the diversity [111]. Finally, the patent MX2017013652 describes a method to increase the secondary metabolites levels in oregano plants by abiotic stress. Thus, the technology opens perspectives with in vitro cultivars for the obtention of rich crops with potential application as a source of bioactive compounds for functional foods [112]. 


\subsection{Post Pandemic Perspectives}

For the past two years, humankind has been confronted with the massive spread of COVID-19, which has altered the everyday lives of millions of people [113]. Similarly, infection risk encourages market demand for functional foods and Food Complements as a preventive model, according to the literature [114,115]. As a result, the market relies on food products containing bioactive compounds to improve cellular activity, potentially lowering the prevalence and intensity of infection (bacterial, fungal, or viral) $[116,117]$. As a result, it is important to emphasize that incorporating bioactive compounds into a diet would not constitute a "cure," and vaccines have been recommended as a response to COVID-19 by training our bodies to meet the infection.

Alternatively, some experiments show that bioactive substances can serve as auxiliaries against certain illnesses that can affect the proper functioning of the human system. Noor et al. [116] recently released a study demonstrating that the pandemic crisis triggers many psychiatric issues (paranoia, depression, insomnia, etc.) that can result in the production of oxidative stress, which can exacerbate the symptoms. Consequently, polyphenolic compounds (flavonoids, phenolic acid, and so on) have been suggested as health boosters due to their capacity to donate hydrogens or electrons to free radicals, thus stabilizing them [117]. The key component of OEOs, including carvacrol, demonstrated the ability to reduce lung tissue damage (edema, hyperemia, and lymphocyte infiltration) caused by influenza virus $A$, which has been identified because of an overreaction of the innate immune system [118].

Recently, Dr. Cristian Torres-León (co-author) and the CIJE research group used molecular docking (in silico) to assess the effectiveness of the most bioactive compounds found in L. graveolens against COVID-19 protease (Mpro) and replicase (RdRp) [119]. The findings revealed that Luteolin 7-O-glucoside has the maximum binding energy against Mpro, with a value of $-8.2 \mathrm{kcal} / \mathrm{mol}$. These findings outperformed those obtained with the antiviral chemical compounds lopinavir $(-7.5 \mathrm{kcal} / \mathrm{mol})$ and ribavirin $(-6.4 \mathrm{kcal} / \mathrm{mol})$. The binding energy of Luteolin 7-O-glucoside $(-10.1 \mathrm{kcal} / \mathrm{mol})$ against $\mathrm{RdRp}$ was found to be higher than that of the antiviral medications Remdesivir, Lopinavir, and Ribavirin $(-8.4$ to $-9.9 \mathrm{kcal} / \mathrm{mol})$. The findings show that the compounds found in Mexican oregano can serve as possible inhibitors of the COVID-19 Mpro and RdRp proteins. Finally, it can be suggested oregano bioactive compounds can be used to improve human health, but further research into kinetics, bioacceptability, biotransformation, and concentration is needed to determine the best scientific method.

\section{Conclusions}

The oregano plant comprises a crop with great economic relevance according to its commercialization as a culinary herb in the food industry; likewise, the phytochemical richness of the material allows it to be considered as a possible source of bioactive compounds with industrial potential (antimicrobial and antioxidant) of interest for the consumer. On the other hand, it is important to point out that technological development around Mexican species can be expanded through the incorporation of new extraction technologies and the development of new products that use the components present in the plant. Finally, it is important to note that current studies on Mexican oregano are mainly focused on the analysis of essential oils and hydroalcoholic extracts of fresh plant material, leaving the door open for future research that seeks to encourage the use of residual material resulting from EO extraction processes through characterization analysis, determination of bioactive potentials or favorable extraction methods that add an extra value to the plant.

Author Contributions: I.B.-H. conceived and designed the idea and wrote the manuscript; G.C.G.M.Á., A.I., A.C.F.-G. and C.T.-L. wrote and reviewed the manuscript; C.N.A. and M.L.C.-G. conceived and designed the idea and wrote and reviewed the manuscript; D.K.V. provided technical assistance, scientific correction, and language revision for the final versions of the manuscript. All authors have read and agreed to the published version of the manuscript. 
Funding: This research was funded by Fondo Sectorial de Investigación para la Educación (CB 2017-2018) Proyecto A1-S-42515.

Institutional Review Board Statement: Not Applicable.

Informed Consent Statement: Not Applicable.

Acknowledgments: To CONACYT for the support of the scholarship granted (777755) to the student IBH.

Conflicts of Interest: The authors declare no conflict of interest.

\section{References}

1. Calvo-Irabién, L.M.; Parra-Tabla, V.; Acosta-Arriola, V.; Escalante-Erosa, F.; Díaz-Vera, L.; Dziba, G.R.; Peña-Rodríjuez, L.M. Essential Oils of Mexican Oregano (Lippia graveolens Kunth) Populations along an Edapho-Climatic Gradient. J. Chem. Biodivers. 2014, 11, 1010-1021. [CrossRef]

2. Soto-Armenta, L.C.; Sacramento-Rivero, J.C.; Acereto-Escoffié, P.O.; Peraza-González, E.E.; Reyes-Sosa, C.F.; Rocha-Uribe, J.A. Extraction Yield of Essential Oil from Lippia graveolens Leaves by Steam Distillation at Laboratory and Pilot Scales. Har Krishan Bhalla Sons 2017, 20, 610-621. [CrossRef]

3. Cheikhyoussef, A.; Cheikhyoussef, N.; Ramadan, M. Cold pressed oregano (Origanum vulgare) oil. In Cold Pressed Oils; Ramadan, M.F., Ed.; Academic Press: Cambridge, MA, USA, 2020; pp. 289-293.

4. Gutiérrez-Grijalva, E.P.; Antunes-Ricardo, M.; Acosta-Estrada, B.A.; Gutiérrez-Uribe, J.A.; Heredia, J.B. Cellular antioxidant activity and in vitro inhibition of $\alpha$-glucosidase, $\alpha$ - amylase and pancreatic lipase of oregano polyphenols under simulated gastrointestinal digestion. Int. Food Res. J. 2019, 116, 676-686. [CrossRef]

5. Ortega-Ramirez, L.A.; Rodríguez-Garcia, I.; Silva-Espinoza, B.A.; Ayala-Zavala, J.F. Oregano (Origanum spp.) Oils. In Essential Oils in Food Preservation; Preedy, V.R., Ed.; Academic Press: Cambridge, MA, USA, 2016; pp. 625-629.

6. Díaz-de León, C.I.; Gónzález-Álvarez, M.A.; Guzmán-Lucio, M.A.; Nuñez-Gúzman, G.R.; Moreno-limón, S. The oregano of the genus Lippia (Verbenaceae) and Poliomintha (Lamiaceae) in the state of Nuevo León, Mexico. Poliboténica 2020, 50, 1-18. [CrossRef]

7. Torres-León, C.; Ventura-Sobrevilla, J.; Serna-Cock, L.; Ascacio-Valdés, J.A.; Contreras-Esquivel, J.; Aguilar, C.N. Pentagalloylglucose (PGG): A valuable phenolic compound with functional properties. J. Funct. Foods 2017, 37, 176-189. [CrossRef]

8. Cui, H.; Zhanga, C.; Lib, C.; Lina, L. Antibacterial mechanism of oregano essential oil. J. Ind. Crop. Prod. 2019, 139. [CrossRef]

9. Turek, C.; Stintzing, F.C. Stability of Essential Oils: A Review. Compr. Rev. Food Sci. F. 2013, 12. [CrossRef]

10. Ren, M. Targeting Open Market with Strategic Business Innovations: A Case Study of Growth Dynamics in Essential Oil and Aromatherapy Industry. J. Open Innov. Technol. Mark. Complex 2019, 5, 7. [CrossRef]

11. Codex Alimentarius Commission. Food Standards Programme Codex Committee on Spices and Culinary Herb, Thiruvananthapuram, India, 21-25 January 2019. Available online: http:/ / www.fao.org / fao-who-codexalimentarius/shproxy/zh/?lnk=1\& url=https \%253A \%252F\%252Fworkspace.fao.org\%252Fsites \%252Fcodex\%252FMeetings \%252FCX-736-04\%252FCRDS\%252Fsc0 4_crd04x.pdf (accessed on 5 March 2021).

12. Granados-Sánchez, D.; Martínez-Salvador, M.; López-Ríos, G.; Borja-De la Rosa, A.; Rodríguez-Yam, G. Ecology, harvesting and marketing of oregano (Lippia graveolens H. B. K.) in Mapimí, Durango. Rev. Chapingo. Ser. Cienc. For. y Ambiente 2013, 19, 305-322.

13. Reyes-Jurado, F.; Cervantes-Rincón, T.; Bach, H.; López-Malo, A.; Palou, E. Antimicrobial activity of Mexican oregano (Lippia berlandieri), thyme (Thymus vulgaris), and mustard (Brassica nigra) essential oils in gaseous phase. Ind. Crop. Prod. 2019, 131, 90-95. [CrossRef]

14. Bayir, A.G.; Kiziltan, H.S.; Kocyigit, A. Plant Family, Carvacrol, and Putative Protection in Gastric Cancer. In Dietary Interventions in Gastrointestinal Diseases Foods, Nutrients, and Dietary Supplements; Watson, R.R., Preedy, V.R., Eds.; Academic Press: Cambridge, MA, USA, 2019; pp. 3-18.

15. Arias, J.; Mejía, J.; Córdoba, Y.; Martínez, J.R.; Stashenko, E. Optimization of flavonoids extraction from Lippia graveolens and Lippia origanoides chemotypes with ethanol-modified supercritical $\mathrm{CO}_{2}$ after steam distillation. Ind. Crop. Prod. 2020, 146, 112170. [CrossRef]

16. Rassem, H.; Nour, A.; Yunus, R. Biological activities of essential oils-A review. J. Pac. Int. 2018, 2, 63-76.

17. Rehman, R.; Hanif, M.; Mushtaq, Z.; Al-Sadi, A. Biosynthesis of essential oils in aromatic plants: A review. Food Rev. Int. 2016, 32, 117-160. [CrossRef]

18. Ludwiczuk, A.; Skalicka-Wozniak, K.; Georgiev, M.I. Terpenoids. In Pharmacognosy: Fundamentals, Applications and Strategies; Badal, S., Delgoda, R., Eds.; Academic Press: Cambridge, MA, USA, 2017. [CrossRef]

19. Cid-Pérez, T.S.; Ávila-Sosa, R.; Ochoa-Velasco, C.E.; Rivera-Chavira, B.E.; Nevárez-Moorillón, G.V. Antioxidant and Antimicrobial Activity of Mexican Oregano (Poliomintha longiflora) Essential Oil, Hydrosol and Extracts fromWaste Solid Residues. Plants 2019, 8, 22. [CrossRef] [PubMed]

20. Bayramoglu, B.; Sahin, S.; Summu, G. Solvent-free microwave extraction of essential oil from oregano. J. Food Eng. 2008, 88, 535-540. [CrossRef]

21. Figiel, A.; Szumny, A.; Gutiérrez-Ortíz, A.; Carbonell-Barrachina, Á.A. Composition of oregano essential oil (Origanum vulgare) as affected by drying method. J. Food Eng. 2010, 98, 240-247. [CrossRef] 
22. Gerami, F.; Moghaddam, P.R.; Ghorbani, R.; Hassani, A. Effects of irrigation intervals and organic manure on morphological traits, essential oil content and yield of oregano (Origanum vulgare L.). Anais da Academia Brasileira de Ciências 2016, 88, $2375-2385$. [CrossRef]

23. Morshedloo, M.R.; Mumivand, H.; Craker, L.E.; Maggi, F. Chemical composition and antioxidant activity of essential oils in Origanum vulgare subsp. gracile at different phenological stages and plant parts. J. Food Process. Preserv. 2017, 42. [CrossRef]

24. Toncer, O.; Karaman, S.; Kizil, S.; Diraz, E. Changes in Essential Oil Composition of Oregano (Origanum onites L.) due to Diurnal Variations at Different Development Stages. Not. Bot. Horti Agrobot. Cluj-Napoca 2009, 37, 177-181.

25. Leyva-López, N.; Nair, V.; Banh, W.Y.; Cisneros-Zevallos, L.; Basilio Heredia, J. Protective role of terpenes and polyphenols from three species of Oregano (Lippia graveolens, Lippia palmeri and Hedeoma patens) on the suppression of lipopolysaccharide-induced inflammation in RAW 264.7 macrophage cells. J. Ethnopharmacol. 2016, 187, 302-312. [CrossRef] [PubMed]

26. Cortés-Chital, M.C.; Flores-Martínez, H.; Orozco-Ávila, I.; León-Campos, C.; Suárez-Jacobo, Á.; Estarrón-Espinosa, M. Identification and Quantification of Phenolic Compounds from Mexican Oregano (Lippia graveolens HBK) Hydroethanolic Extracts and Evaluation of Its Antioxidant Capacity. Molecules 2021, 26, 702. [CrossRef]

27. Barbieri, N.; Sanchez-Contreras, A.; Canto, A.; Cauich-Rodriguez, J.V.; Vargas-Coronado, R.; Calvo-Irabien, L.M. Effect of cyclodextrins and Mexican oregano (Lippia graveolens Kunth) chemotypes on the microencapsulation of essential oil. Ind. Crop. Prod. 2018, 121, 114-123. [CrossRef]

28. Herrera-Rodríguez, S.E.; López-Rivera, R.J.; García-Márquez, E.; Estarrón-Espinosa, M.; Espinosa-Andrews, H. Mexican oregano (Lippia graveolens) essential oil-in-water emulsions: Impact of emulsifier type on the antifungal activity of Candida albicans. Food Sci. Biotechnol. 2019, 28, 441-448. [CrossRef] [PubMed]

29. Cid-Pérez, T.S.; Nevárez-Moorillón, G.V.; Torres-Muñoz, J.V.; Palou, E.; López-Malo, A. Mexican oregano (Lippia berlandieri and Poliomintha longiflora) oils. In Essential Oils in Food Preservation, Flavor and Safety; Elsevier: Amsterdam, The Netherlands, 2016; pp. 551-560. [CrossRef]

30. Irrera, N.; D'ascola, A.; Pallio, G.; Bitto, A.; Mannino, F.; Arcoraci, V. $\beta$-caryophyllene inhibits cell proliferation through a direct modulation of CB2 receptors in glioblastoma cells. Cancers 2020, 12, 1038. [CrossRef]

31. De Meireles, A.L.P.; da Silva Rocha, K.A.; Kozhevnikova, E.F.; Kozhevnikov, I.V.; Gusevskaya, E.V. Heteropoly acid catalysts for the valorization of biorenewables: Isomerization of caryophyllene oxide in green solvents. Mol. Catal. 2018, 458, $213-222$. [CrossRef]

32. Ngamprasertsith, S.; Menwa, J.; Sawangkeaw, R. Caryophyllene oxide extraction from lemon basil (Ocimum citriodorum Vis.) straw by hydrodistillation and supercritical CO2. J. Supercrit. Fluids 2018, 138, 1-6. [CrossRef]

33. Chavan, M.J.; Wakte, P.S.; Shinde, D.B. Analgesic and anti-inflammatory activity of Caryophyllene oxide from Annona squamosa L. bark. Phytomedicine 2010, 17, 149-151. [CrossRef] [PubMed]

34. Hartsel, J.A.; Eades, J.; Hickory, B.; Makriyannis, A. Cannabis sativa and Hemp. In Nutraceuticals: Efficacy, Safety and Toxicity; Gupta, R.C., Ed.; Elsevier: Amsterdam, The Netherlands, 2016; pp. 735-754. [CrossRef]

35. Russo, E.B.; Marcu, J. The Usual Suspects and a Few Promising Leads. In Cannabis Pharmacology; Advances in Pharmacology, 1st ed.; Elsevier: Amsterdam, The Netherlands, 2017; Volume 80, pp. 67-134. [CrossRef]

36. Oliveira, R.; Balbino, E.; Carvalho, R.; Antunes, A.; Gomes, T.; Fernandes, R.; Coelho, G.B.; Carvalho, G.; Mendes, K.; Formiga, M.F.; et al. Effect of p-cymene and rosmarinic acid on gastric ulcer healing-Involvement of multiple endogenous curative mechanisms. Phytomedicine 2021, 86, 153497. [CrossRef]

37. Pilau, M.R.; Alves, S.H.; Weiblen, R.; Arenhart, S.; Cueto, A.P.; Lovato, L.T. Antiviral activity of the Lippia graoveolens (Mexican oregano) essential oil and its main compound carvacrol against human and animal viruses. Braz. J. Microbiol. 2011, 42, 1616-1624. [CrossRef]

38. Mediouni, S.; Jablonski, J.A.; Tsida, S.; Barsamian, A.; Kessing, C.; Richard, A.; Biswas, A.; Toledo, F.; Andrade, V.M.; Even, Y.; et al. Oregano Oil and Its Principal Component, Carvacrol, Inhibit HIV-1 Fusion into Target Cells. J. Virol. 2020, 94, 15. [CrossRef]

39. Asif, M.; Saleem, M.; Saadullah, M.; Yaseen, H.S.; Zarzour, R.A. COVID-19 and therapy with essential oils having antiviral anti-inflammatory, and immunomodulatory properties. Inflammopharmacology 2020, 28, 1153-1161. [CrossRef] [PubMed]

40. Muturi, E.; Ramirez, J.; Doll, M.K.; Bowman, M.J. Combined Toxicity of Three Essential Oils Against Aedes aegypti (Diptera: Culicidae) Larvae. J. Med. Entomol. 2017, 1-8. [CrossRef]

41. Rosa, D.S.; Vargas, B.P.; Silveira, M.V.; Rosa, C.H.; Martins, M.L.; Rosa, G.R. On the Use of Calcined Agro-Industrial Waste as Palladium Supports in the Production of Eco-Friendly Catalysts: Rice Husks and Banana Peels Tested in the Suzuki-Miyaura Reaction. Waste Biomass Valorization 2019, 10, 2285-2296. [CrossRef]

42. Gan, R.-Y.; Chan, C.-L.; Yang, Q.-Q.; Li, H.-B.; Zhang, D.; Ge1, Y.-Y.; Gunaratne, A.; Ge1, J.; Corke, H. Bioactive compounds and beneficial functions of sprouted grains. In Sprouted Grains: Nutritional Value, Production and Applications; Feng, H., Nemzer, B., DeVries, J.W., Eds.; AACC International Press: Cambridge, MA, USA, 2019. [CrossRef]

43. Babu, P.V.A.; Liu, D. Flavonoids and Cardiovascular Health. In Complementary and Alternative Therapies and the Aging Population; Watson, R.R., Ed.; Academic Press: Cambridge, MA, USA, 2009. [CrossRef]

44. Gutiérrez-Grijalva, E.P.; Picos-Salas, M.A.; Leyva-López, N.; Criollo-Mendoza, M.S.; Vazquez-Olivo, G.; Heredia, J.B. Flavonoids and Phenolic Acids from Oregano: Occurrence, Biological Activity and Health Benefits. Plants 2017, 7, 2. [CrossRef] 
45. Wang, T.-Y.; Li, Q.; Bi, K.-S. Bioactive flavonoids in medicinal plants: Structure, activity and biological fate. Asian J. Pharm. Sci. 2018, 13, 12-23. [CrossRef]

46. Cálinoiu, L.F.; Vodnar, D.C. Thermal Processing for the Release of Phenolic Compounds from Wheat and Oat Bran. Biomolecules 2019, 10, 21. [CrossRef] [PubMed]

47. Bacanli, M.; Başaran, A.A.; Başaran, N. Galangin as a plant phenolic and usage in health and disease. In Polyphenols Prevention and Treatment of Human Disease; Academic Press: Cambridge, MA, USA, 2018; pp. 433-438.

48. Ramos-Tovar, E.; Muriel, P. Phytotherapy for the Liver. In Dietary Interventions in Liver Disease: Foods, Nutrients, and Dietary Supplements; Watson, R.R., Preedy, V.R., Eds.; Academic Press: Cambridge, MA, USA, 2019; pp. 101-121. [CrossRef]

49. Hasanein, P.; Emamjomeh, A. Beneficial Effects of Natural Compounds on Heavy Metal-Induced Hepatotoxicity. In Dietary Interventions in Liver Disease: Foods, Nutrients, and Dietary Supplements; Watson, R.R., Preedy, V.R., Eds.; Academic Press: Cambridge, MA, USA, 2019; pp. 345-355. [CrossRef]

50. Bekut, M.; Brkić, S.; Kladar, N.; Dragović, G.; Gavarić, N.; Božin, B. Potential of selected Lamiaceae plants in anti(retro)viral therapy. Pharmacol. Res. 2018, 133, 301-314. [CrossRef]

51. Tiwari, N.; Kumar, A.; Singh, A.K.; Bajpai, S.; Agrahari, A.K.; Kishore, D. Leishmaniasis control: Limitations of current drugs and prospects of natural products. In Discovery and Development of Therapeutics from Natural Products against Neglected Tropical Diseases; Brahmachari, G., Ed.; Elsevier: Amsterdam, The Netherlands, 2019; pp. 293-350. [CrossRef]

52. Torres-León, C.; Chávez-González, M.L.; Hernández-Almanza, A.; Martínez-Medina, G.A.; Ramírez-Gúzman, N.; LondoñoHernández, L.; Aguilar, C.N. Recent advances on the microbiological and enzymatic processing for conversion of food wastes to valuable bioproducts. Curr. Opin. Food Sci. 2020, 35, 40-45. [CrossRef]

53. Méndez-Tovar, I.; Herrero, B.; Pérez-Magariño, S.; Pereira, J.A.; Asensio-S-Manzanera, M.C. By-product of Lavandula latifolia essential oil distillation as source of antioxidants. J. Food Drug Anal. 2014, 1-8. [CrossRef]

54. Oreopoulou, A.; Goussias, G.; Tsimogiannis, D.; Oreopoulou, V. Hydro-alcoholic extraction kinetics of phenolicsfrom oregano: Optimization of the extractionparameters. Food Bioprod. Process. 2020, 123, 378-389. [CrossRef]

55. Sasidharan, S.; Chen, Y.; Saravanan, D.; Sundram, K.M.; Yoga, L. Extraction, isolation and characterization of bioactive compounds from plants' extracts. Afr. J. Tradit. Complement Altern. Med. 2011, 8, 1-10. [CrossRef] [PubMed]

56. Ngoc-Minh, T.; Dang-Xuan, T.; Hoang-Dung, T.; Mai-Van, T.; Andriana, Y.; Dnag-Khanh, T.; Van-Quan, N.; Ahmad, A. Isolation and Purification of Bioactive Compounds from the Stem Bark of Jatropha podagrica. Molecules 2019, 24, 889. [CrossRef] [PubMed]

57. Manouchehria, R.; Saharkhiza, M.J.; Karamia, A.; Niakousarib, M. Extraction of essential oils from damask rose using green and conventional techniques: Microwave and ohmic assisted hydrodistillation versus hydrodistillation. J. Sustain. Chem. Pharm. 2018, 8, 76-81. [CrossRef]

58. Valderrama, F.; Ruiz, F. An optimal control approach to steam distillation of essential oils from aromatic plants. J. Comput. Chem. Eng. 2018, 117, 25-31. [CrossRef]

59. Saucedo-Pompaa, S.; Torres-Castilloc, J.A.; Castro-López, C.; Rojas, R.; Sánchez-Alejo, E.J.; Ngangyo-Heya, M.; Martínez-Ávilaa, G.C.G. Moringa plants: Bioactive compounds and promising applications in Food products. J. Food Res. Int. 2018, 111, 438-450. [CrossRef] [PubMed]

60. Perovic, A.; Stankovic, M.Z.; Veljkovic, E.B.M.; Kostic, M.D.; Stamenkovic, O.S. A further study of the kinetics and optimization of the essential oil hydrodistillation from lavender flowers. Chin. J. Chem. Eng. 2020, 29, 126-130. [CrossRef]

61. Cinbilgel, I.; Kurt, Y. Oregano and/or Marjoram: Traditional Oil Production and Ethnomedical Utilization of Origanum Species in southern Turkey. J. Herb. Med. 2019, 16, 100257. [CrossRef]

62. Mahanta, B.P.; Sarma, N.; Kemprai, P.; Begum, T.; Saikia, L.; Lal, M.; Haldar, S. Hydrodistillation based multifaceted value addition to Kaempferia galanga L. leaves, an agricultural residue. Ind. Crop. Prod. 2020, 154, 112642. [CrossRef]

63. Hashemi, S.M.B.; Nikmaram, N.; Esteghlal, S.; Khaneghah, A.M.; Niakousari, M.; Barba, F.J.; Roohinejad, S.; Koubaa, M. Efficiency of Ohmic assisted hydrodistillation for the extraction of essential oils from oregano (Origanum vulgare subsp. viride) spices. Innov. Food Sci. Emerg. Tech. 2017, 41, 172-178. [CrossRef]

64. Rassem, H.H.A.; Nour, A.H.; Yunus, R.M. Techniques For Extraction of Essential Oils From Plants: A Review. Aust. J. Basic Appl. Sci. 2016, 10, 117-127.

65. Khalil, A.A.; Rahman, U.; Khan, M.; Sahar, A.; Mehmoodac, T.; Khana, M. Essential oil eugenol: Sources, extraction techniques and nutraceutical perspectives. J. R. Soc. Chem. 2017, 7, 32669-32681. [CrossRef]

66. Prado, J.M.; Vardanega, R.; Debien, I.C.N.; Meireles, M.A.A.; Gerschenson, L.N.; Sowbhagya, H.B. Conventional Extraction; Chapter 6; Elsevier: Amsterdam, The Netherlands, 2015. [CrossRef]

67. Asbahani, A.; Miladi, K.; Badri, W.; Sala, M.; Aït Addi, E.H.; Casabianca, H.; Mousadik, A.; Hartmann, D.; Jilale, A.; Renaud, F.N.R.; et al. Essential oils: From extraction to encapsulation. Int. J. Pharm. 2015, 483, 220-243. [CrossRef]

68. González-Trujano, M.E.; Hernández-Sánchez, L.Y.; Ocotero, V.M.; Dorazco-González, A.; Fefer, P.G.; Aguirre-Hernández, E. Pharmacological evaluation of the anxiolytic-like effects of Lippia graveolens and bioactive compounds. Pharm. Biol. 2017, 55, 1569-1576. [CrossRef]

69. Chanioti, S.; Tzia, C. Extraction of phenolic compounds from olive pomace by using natural deep eutectic solvents and innovative extraction techniques. J. Innov. Food Sci. Emerg. Technol. 2018, 48, 228-239. [CrossRef]

70. Mohammadpour, H.; Sadrameli, S.M.; Eslami, F.; Asoodeh, A. Optimization of ultrasound-assisted extraction of Moringa peregrina oil with response surface methodology and comparison with Soxhlet method. Ind. Crop. Prod. 2019, 131, 106-116. [CrossRef] 
71. Mandal, S.; Mandal, V.; Kumar-Das, A. Essentials of Botanical Extraction: Principles and Applications; Academic Press: Cambridge, MA, USA, 2015; Volume 1, p. 220. [CrossRef]

72. Trejo-Márquez, M.A.; Vargas-Martínez, M.G.; Sánchez-Soto, A.; Adela, L.V.A.; Pascual-Bustamante, S.; Granados, G.; Villavicencio, A.G. Extraction of bioactive compounds of plants from the Mexican desert for its applitacion in active packaging for blackberry. Rev. Iberoam. Tecnol. Postcosecha 2015, 16, 101-107.

73. Rehman, M.U.; Khan, A.F.; Niaz, K. Introduction to natural products analysis. In Recent Advances in Natural Products Analysis; Silva, A.S., Nbavi, S.F., Saeedi, M., Nabavi, S.M., Eds.; Academic Press: Cambridge, MA, USA, 2020; pp. 1-13.

74. Llompart, M.; Garcia-Jares, C.; Celeiro, M. Microwave-Assisted Extraction. Reference Module in Chemistry. Mol. Sci. Chem. Eng. 2019, 67-77. [CrossRef]

75. Reddy, A.V.B.; Moniruzzaman, M.; Madhavi, V.; Jaafar, J. Recent improvements in the extraction, cleanup and quantification of bioactive flavonoids. Stud. Nat. Prod. Chem. 2020, 66, 197-223. [CrossRef]

76. Kataoka, H. Pharmaceutical Analysis, Sample Preparation. In Encyclopedia of Analytical Science, 2nd ed.; Wosfold, P., Townshend, A., Poole, C., Eds.; Elsevier: Oxford, UK, 2005; pp. 107-116. ISBN 9780123693976.

77. Drinić, Z.; Pljevljakušić, D.; Živković, J.; Bigović, D.; Šavikin, K. Microwave-assisted extraction of O. vulgare L. spp. hirtum essential oil: Comparison with conventional hydro-distillation. Food Bioprod. Process. 2020, 120, 158-165. [CrossRef]

78. Vichi, S. Chapter 66-Extraction Techniques for the Analysis of Virgin Olive Oil Aroma. In Olives and Olive Oil in Health and Disease Prevention; Academic Press: Cambridge, MA, USA, 2010; pp. 615-623. [CrossRef]

79. Verma, D.K.; Dhakane, J.P.; Mahato, D.K.; Billoria, S.; Bhattacharjee, P.; Srivastav, P.P. Supercritical Fluid Extraction (SCFE) for Rice Aroma Chemicals: Recent and Advance Extraction Method. Science and Technology of Aroma, Flavour and Fragrance in Rice; Verma, D.K., Srivastav, P.P., Eds.; Apple Academic Press: San Diego, CA, USA, 2018; pp. 93-140.

80. Verma, D.K.; Srivastav, P.P. A Paradigm of Volatile Aroma Compounds in Rice and Their Product with Extraction and Identification Methods: A Comprehensive Review. Food Res. Int. 2020, 130, 1-33. [CrossRef]

81. Verma, D.K.; Srivastav, P.P. Extraction, Identification and Quantification Methods of Rice Aroma Compounds with Emphasis on 2-Acetyl-1-Pyrroline (2-AP) and Its Relation with Rice Quality: A Comprehensive Review. Food Rev. Int. 2020. [CrossRef]

82. Chávez-González, M.L.; Sepúlveda, L.; Verma, D.K.; Luna-García, H.A.; Rodríguez-Durán, L.V.; Ilina, A.; Aguilar, C.N. Conventional and Emerging Extraction Processes of Flavonoids. Processes 2020, 8, 434. [CrossRef]

83. Abhari, K.; Mousavi, A. Alternative extraction techniques to obtain, isolate and purify proteins and bioactive from aquaculture and by-products. In Advances in Food and Nutrition Research, 1st ed.; Toldrá, F., Ed.; Elsevier: Amsterdam, The Netherlands, 2020; Volume 92, pp. 35-52. [CrossRef]

84. Wang, Q.; Sho, A.; Liu, H.; Liu, L.; Zhang, Y.; Li, N.; Gong, K.; Yu, M.; Zheng, L. Peanut by-products utilization technology. In Peanuts: Processing Technology and Product Development; Wang, Q., Ed.; Academic Press: Cambridge, MA, USA, 2016; pp. 211-325.

85. Peter, K.V. Handbook of Herbs and Spices; Woodhead Publishing: Sawston, UK, 2012; Volume 1, p. 607.

86. Chin Chew, S. Cold-pressed rapeseed (Brassica napus) oil: Chemistry and functionality. Food Res. Int. 2020, 131, 108997. [CrossRef]

87. Silva, S.G.; de Oliveira, M.S.; Cruz, J.N.; da Costa, W.A.; da Silva, S.H.M.; Barreto Maia, A.A.; de Sousa, R.L.; Carvalho Junior, R.N.; de Aguiar Andrade, E.H. Supercritical CO2 extraction to obtain Lippia thymoides Mart. \& Schauer (Verbenaceae) essential oil rich in thymol and evaluation of its antimicrobial activity. J. Supercrit. Fluids 2021, 168, 105064. [CrossRef]

88. De Oliveira, M.S.; Silva, S.G.; da Cruz, J.N.; Ortiz, E.; da Costa, W.A.; Bezerra, F.W.F.; Cunha, V.M.B.; Cordeiro, R.M.; de Jesus Chaves Neto, A.M.; de Aguiar Andrade, E.H.; et al. Supercritical CO2 Application in Essential Oil Extraction. In Industrial Applications of Green Solvents; Inamuddin, R.M., Asiri, A.M., Eds.; Materials Research Foundations: Millersville, PA, USA, 2019; Volume 2, pp. 1-28. [CrossRef]

89. Soto-Armenta, L.C.; Rivero, J.C.S.; Ruiz-Mercado, C.A.; Lope-Navarrete, M.C.; Rocha-Uribe, J.A. Extraction yield and kinetic study of Lippia graveolens with supercritical $\mathrm{CO}_{2}$. J. Supercrit. Fluids 2018, 145, 205-210. [CrossRef]

90. García-Pérez, J.S.; Robledo-Padilla, F.; Cuellar-Bermudez, S.P.; Arevalo-Gallegos, A.M.; Parras-Saldivar, R.; Zavala-Yoe, R.; Ramirez-Mendoza, R.A.; Iqbal, M.N. Thermodynamics and statistical correlation between supercritical- $\mathrm{CO}_{2}$ fluid extraction and bioactivity profile of locally available Mexican plants extracts. J. Supercrit. Fluids 2016, 122, 27-34. [CrossRef]

91. Borgarello, A.V.; Mezza, G.N.; Pramparo, M.C.; Gayol, M.F. Thymol enrichment from oregano essential oil by molecular distillation. Sep. Purif. Technol. 2015, 153, 60-66. [CrossRef]

92. Ameer, K.; Shahbaz, H.M.; Kwon, J.-H. Green Extraction Methods for Polyphenols from Plant Matrices and Their Byproducts: A Review. Compr. Rev. 2017, 16, 295-315. [CrossRef]

93. Conde-Hernández, L.A.; Espinosa-Victoria, J.R.; Trejo, A.; Guerrero-Beltrán, J.A. $\mathrm{CO}_{2}$-Supercritical extraction, hydrodistillation and steam distillation of essential oil of rosemary (Rosmarinus officinalis). J. Food Eng. 2016, 200, 81-86. [CrossRef]

94. García-Bores, A.M.; Espinosa-González, A.M.; Reyna-Campos, A.; Cruz-Toscano, S.; Benítez-Flores, J.C.; Hernández-Delgado, C.T.; Flores-Maya, S.; Urzúa-Meza, M.; Peñalosa-Castro, I.; Céspedes-Acuña, C.L.; et al. Lippia graveolens photochemopreventive effect against UVB radiation-induced skin carcinogenesis. J. Photochem. Photobiol. B Biol. 2016. [CrossRef]

95. Amador, S.; Nieto-Camacho, A.; Ramírez-Apan, M.T.; Matínez, M.; Maldonado, E. Cytotoxic, anti-inflammatory, and $\alpha-$ glucosidase inhibitory effects of flavonoids from Lippia graveolens (Mexican oregano). Med. Chem. Res. 2020, 29, 1497-1506. [CrossRef] 
96. Lu-Martínez, A.A.; Báez-González, J.G.; Castillo-Hernández, S.; Amaya-Guerra, C.; Rodríguez-Rodríguez, J.; García-Márquez, E. Studied of Prunus serotine oil extracted by cold pressing and antioxidant effect of P. longiflora essential oil. J. Food Sci. Technol. 2020, 58, 1420-1429. [CrossRef]

97. Boroski, M.; Giroux, H.J.; Sabik, H.; Petit, H.V.; Visentainer, J.V.; Matumoto-Pintro, P.V.; Britten, M. Use of oregano extract and oregano essential oil as antioxidants in functional dairy beverage formulations. LWT Food Sci. Tech. 2012, 47, 167-174. [CrossRef]

98. Chuang, L.-T.; Tsai, T.-H.; Lien, T.-J.; Huang, W.-C.; Liu, J.-J.; Chang, H.; Chang, M.-L.; Tsai, P.-J. Ethanolic Extract of Origanum vulgare Suppresses Propionibacterium acnes-Induced Inflammatory Responses in Human Monocyte and Mouse Ear Edema Models. Molecules 2018, 23, 1987. [CrossRef]

99. Dávila-Rodríguez, M.; López-Malo, A.; Palou, E.; Ramírez-Corona, N.; Jiménez-Munguía, M.T. Essential oils microemulsions prepared with high-frequency ultrasound: Physical properties and antimicrobial activity. J. Food Sci. Technol. 2020, 57, 4133-4142. [CrossRef] [PubMed]

100. Alagawany, M.; Abd El-Hack, M.E.; Farag, M.R.; Shaheen, H.M.; Abdel-Latif, M.A.; Noreldin, A.E. The usefulness of oregano and its derivatives in poultry nutrition. Worlds Poult. Sci. J. 2018, 74, 463-473. [CrossRef]

101. Hernández-Coronado, A.C.; Silva-Vázquez, R.; Rangel-Nava, Z.E.; Hernández-Martínez, C.A.; Kawas-Garza, J.R.; Hume, M.E. Mexican oregano essential oils given in drinking water on performanc6e, carcass traits, and meat quality of broilers. Poult. Sci. 2019, 98, 3050-3058. [CrossRef]

102. Bauer, B.W.; Radovanovic, A.; Willson, N.-L.; Bajagai, Y.S.; Van, T.T.H.; Moore, R.J.; Stanley, D. Oregano: A potential prophylactic treatment for the intestinal microbiota. Heliyon 2019, 5, e02625. [CrossRef]

103. Ríos, N.; Stashenko, E.E.; Duque, J.E. Evaluation of the insecticidal activity of essential oils and their mixtures against Aedes aegypti (Diptera: Culicidae). Rev. Bras. Entomol. 2017, 61, 307-311. [CrossRef]

104. Govindarajan, M.; Rajeswary, M.; Hoti, S.L.; Benelli, G. Larvicidal potential of carvacrol and terpinen-4-ol from the essential oil of Origanum vulgare (Lamiaceae) against Anopheles stephensi, Anopheles subpictus, Culex quinquefasciatus and Culex tritaeniorhynchus (Diptera: Culicidae). Res. Vet. Sci. 2016, 104, 77-82. [CrossRef]

105. Castilho, C.V.V.; Leitão, S.G.; Silva, V.D.; Miranda, C.O.; da Santos, M.C.S.; Bizzo, H.R. In vitro propagation of a carvacrolproducing type of Lippia origanoides Kunth: A promising oregano-like herb. Ind. Crop. Prod. 2019, 130, 491-498. [CrossRef]

106. Gavin-Martin, J. Smokable Remedial Herb Blend. Spanish Patent ES2678597, 14 August 2018.

107. López-Gómez, A.; Ros-Chumillas, M. Composition of Ice with Antimicrobial Activity, Manufacturing Method, and Its Applications. Spanish Patent ES2613240, 9 May 2017.

108. Ninkov, D. Antimicrobial Therapeutic Compositions and Procedures for Use. Spanish Patent ES2351116, 31 January 2011.

109. Lira, R.H.; Hernández, M. Natural Compounds Having Antimicrobial Activity for Preventing and Controlling Infectious Diseases in Humans and Food. Mexican Patent MXNL/A/2006/000057, 31 October 2008.

110. Yanez-Reyes, J.N. Formulation Stimulating Plant Growth and Development and Resistance Inducer for the Control of Diseases Caused by Phytopatogenic Viruses and Method of Preparation. Spanish Patent ES2628278, 2 August 2017.

111. Gutierrez, J.A.; García, S.; García, E. Process for the Regeneration of Mexican Oregano Plants (of the Genus Poliomintha) by Indirect Organogenesis. Mexican Patent MX365079, 28 February 2014.

112. Muñoz, C.V.; Aburto, J.A. Method to Increase the Secondary Metabolites in Candelilla and Oregano. Mexican Patent MX2017013652, 24 April 2019.

113. Ayseli, Y.I.; Aytekin, N.; Buyukkayhan, D.; Aslan, I.; Ayseli, M.T. Food policy, nutrition and nutraceuticals in the prevention and management of COVID-19: Advice for healthcare professionals. Trends Food Sci. Technol 2020, 105, 186-199. [CrossRef] [PubMed]

114. Tripathy, S.; Verma, D.K.; Thakur, M.; Patel, A.R.; Srivastav, P.P.; Singh, S.; Chávez-González, M.L.; Aguilar, C.N. Encapsulated food products as a strategy to strengthen immunity against COVID-19. Front. Nutr. 2021, 8, 245. [CrossRef] [PubMed]

115. Han, B.; Hoang, B.X. Opinions on the current pandemic of COVID-19: Use functional food to boost our immune functions. J. Infect. Public Health 2020, 13, 1811-1817. [CrossRef]

116. Noor, N.; Gani, A.; Gani, A.; Shah, A. International Journal of Biological Macromolecules Exploitation of polyphenols and proteins using nanoencapsulation for anti-viral and brain boosting properties-Evoking a synergistic strategy to combat COVID-19 pandemic. Int. J. Biol. Macromol. 2021, 180, 375-384. [CrossRef] [PubMed]

117. De Souza, E.L.; de Albuquerque, T.M.R.; dos Santos, A.S.; Massa, N.M.L.; de Brito Alves, J.L. Potential interactions among phenolic compounds and probiotics for mutual boosting of their health-promoting properties and food functionalities-A review. Crit. Rev. Food Sci. Nutr. 2019, 59, 1645-1659. [CrossRef]

118. Zheng, K.; Wu, S.Z.; Lv, Y.W.; Pang, P.; Deng, L.; Xu, H.; Chong, X.; Yu-Cong, S.; Xiao-Yin, C. Carvacrol inhibits the excessive immune response induced by influenza virus A via suppressing viral replication and TLR/RLR pattern recognition. J. Ethnopharmacol. 2021, 268, 113555. [CrossRef]

119. Torres-León, C.; Aguirre-Joya, J.A.; Czaja, A.; Aguillón-Gutiérrez, D.R. In silico Screening bioaktiver Verbindungen aus mexikanischen Wüstenpflanzen zur Vorhersage potenzieller Inhibitoren von SARSCoronavirus 2 (SARS-CoV-2). Z Arznei-Gewurzpfla 2020, 24, 153-156. 